\title{
A Batalha Discursiva dos Deputados Federais em Março de $1964^{1}$
}

The Discursive Battle of Representatives in March de 1964

Daniel de MENDONÇA ${ }^{\bullet}$

Resumo. O objetivo do artigo é analisar a batalha discursiva entre os deputados federais na Câmara Federal em março de 1964. De um lado, o discurso contrário ao governo de João Goulart é sustentado pelos deputados de direita. De outro lado, o discurso em defesa do governo é sustentado pelos parlamentares de esquerda. Mais especificamente, os episódios que serão tratados são o "Comício da Central do Brasil", a "Marcha da Família com Deus pela Liberdade" e o "Protesto dos Marinheiros".

Palavras-chave: Governo João Goulart; Comício da Central do Brasil; Marcha da Família com Deus pela Liberdade; Protesto dos Marinheiros.

\begin{abstract}
The aim of this paper is to analyze the discursive battle between federal representatives in Congress in March 1964. On one hand, the speech contrary to the government of João Goulart is backed by representatives from the right. On the other hand, the speech in defense of the government is supported by leftist lawmakers. More specifically, the episodes which will be dealt are the "Rally of the Central do Brazil", "Family Walk with God for Freedom" and the "Protest of the Sailors.
\end{abstract}

Keywords: Goulart's Government; Rally of central do Brasil, the Family Walk with God for Freedom, Protest of the Sailors.

\begin{abstract}
Estamos vivendo numa época em que, infelizmente, a discussão pura de ideias pouco interessa. Todos já tomaram sua posição e de forma inabalável. Estamos diante da luta dos democratas contra os socialistas. Os primeiros, mercê de Deus, estão muito firmes e não se rendem a vãs argumentações. Os segundos não aceitam argumentação de espécie alguma: colocam-se mais numa luta de slogans, de emoções, de coisas passionais, do que mesmo no terreno das ideias. Então é preciso que cada um de nós tome lugar na sua trincheira: que cada um de nós dê seu testemunho. ${ }^{23}$
\end{abstract}

\section{Introdução}

Os acontecimentos políticos ocorridos em março de 1964 foram cruciais para o golpe militar que redundou na deposição de João Goulart e na instauração de um regime autoritário que sobreviveu por 21 anos. Foram cruciais, uma vez que se trataram de uma série de manifestações à direita $^{4}$ e à esquerda ${ }^{5}$ do espectro político, que fizeram com que o mesmo se radicalizasse ainda mais, num já conturbado período que foi o governo de Jango, sobretudo após o retorno dos seus poderes presidenciais com o plebiscito de janeiro do ano anterior.

\footnotetext{
- Professor Doutor - Instituto de Sociologia e Política - UFPel - Univ. Federal de Pelotas - Rua Alberto Rosa, 154, CEP: 96010-770, Pelotas, RS, Brasil. E-mail: ddmendonca@gmail.com
} 
Neste artigo, tendo como pano de fundo as manifestações cada vez mais radicalizadas pró e contrárias a Goulart, será apresentada a batalha discursiva em torno das mesmas na Câmara dos Deputados. Nesse sentido, será verificada a dimensão reativa da Câmara Federal, em relação à situação política contingente do período. Em outras palavras, os principais eventos políticos ocorridos em março de 1964, como o "Comício da Central do Brasil” e a "Marcha da Família com Deus pela Liberdade", tiveram claro reflexo no parlamento brasileiro da época e a explicação do comportamento dos deputados é o principal objetivo deste trabalho.

Nesse sentido, afirma-se aqui de antemão que a principal pauta dos pronunciamentos dos parlamentares girava em torno da profunda instabilidade política do momento. As ações dos mesmos eram, na verdade, reações: reação ao "Comício da Central do Brasil", reação em razão da "Marcha da Família com Deus pela Liberdade", reação ao "Protesto dos Marinheiros", reação aos acontecimentos promovidos pelas centrais sindicais, reação em torno dos decretos presidenciais, como o do congelamento dos aluguéis e o da reforma agrária da SUPRA.

Como se verá, a primeira grande reação parlamentar teve origem a partir do "Comício da Central do Brasil”, organizado pelas principais centrais sindicais brasileiras, em 13 de março, que contou com a participação do próprio presidente João Goulart. Assim, na primeira seção deste artigo, serão apresentados os principais argumentos favoráveis e contrários ao referido ato que movimentou a Câmara Federal ao longo de todo o período final do regime democrático brasileiro. Nas seções seguintes, serão analisados, respectivamente, os pronunciamentos dos parlamentares com relação à "Marcha da Família com Deus pela Liberdade" e em relação ao "Protesto dos Marinheiros” no Rio de Janeiro e a posição política tomada por Goulart naquele episódio.

\section{Direita e esquerda diante da manifestação de Goulart na Central do Brasil}

O pronunciamento pró-reformas de João Goulart no Comício da Central do Brasil gerou forte impacto na Câmara Federal, a qual se transformou em palco de uma verdadeira batalha discursiva em torno de temas como "comunismo", "reformas", "democracia”, “golpe”, "direita”, "esquerda", dentre outros. ${ }^{6}$ Ao longo desta seção, portanto, serão abordados tais temas presentes nos pronunciamentos dos parlamentares. Iniciar-se-á pela reação da "direita".

\section{A reação da direita diante da manifestação de Goulart na Central do Brasil}

A estratégia discursiva do bloco majoritário na Câmara Federal naquele março de 1964, formado pelos parlamentares filiados ao PSD e à UDN, foi a de gerar uma identificação do presidente João Goulart com grupos extremistas de esquerda. Apesar de tanto Goulart como grupos de esquerda, a exemplo do Comando Geral dos Trabalhadores (CGT), desejarem a implementação das "reformas de base", a começar pela reforma agrária, a estratégia do presidente da República 
diferia dos grupos mais radicais, uma vez que a mesma se assentava nos marcos de um projeto de "reformas de base" via reforma constitucional prévia, ou seja, de acordo com os parâmetros legais então vigentes.

Nesse sentido, ainda que muito enfatizada no discurso de Goulart a necessidade de reformas de base, mediante prévia reforma constitucional, a estratégia político-discursiva dos parlamentares de direita na Câmara dos Deputados, sobretudo ligados à UDN e ao PSD, buscava associar a imagem política do presidente com grupos políticos mais radicais, os quais, se assim pudessem, dispensariam o respeito às regras constitucionais para iniciar tais reformas. A constante tentativa de associação do presidente com grupos de esquerda visava a qualificá-lo como "comunista". Tal identificação trazia outros valores negativos a ela associados, uma vez que tal ideologia política era vista como contrária à "tradição" e aos "valores do "povo brasileiro", pois que associada ao ateísmo, dentre outras adjetivações que serão, em breve, melhor evidenciadas. Para iniciar a caracterização do sentido do "comunismo" aos setores direitistas no Parlamento, serão tomados excertos do pronunciamento do deputado federal Padre Vidigal (PSD/MG): $:^{78}$

\begin{abstract}
O SR. PADRE VIDIGAL
(lê a seguinte comunicação)

Sr. Presidente! Srs. Deputados!

No dia 9 de fevereiro dêste ano, o Exmo. Sr. Dom Oscar de Oliveira, dd. Arcebispo de Mariana, dirigiu uma Carta Pastoral sôbre o Comunismo, Religião e Pátria ao Revmo. Clero Diocesano, às Religiosas, a Ação Católica, às Associações Religiosas e aos fiéis em geral.

Esta carta fez com que as palavras do Primaz da Igreja em Minas Gerais repercutissem agradavelmente, no Brasil inteiro, como se fôsse uma clarinada que despertasse o povo para a luta sem tréguas, contra os maiores inimigos da democracia que é de essência evangélica, contra os mais perigosos inimigos de nossa Pátria, pois desejam cubanizá-la, contra os mais rancorosos inimigos de Deus os quais procuram expulsar o Santo Nome d'Êle, das páginas da História, criando o Instituto de Ateísmo Científico e até cursos por correspondência para divulgar o ateísmo.
\end{abstract}

Na saudação de sua comunicação, o deputado anuncia que o seu pronunciamento tem como base a Carta de Dom Oscar de Oliveira, a qual faz uma análise do perigo da ideologia comunista para o Brasil. É interessante observar a utilização que é feita da carta do arcebispo de Mariana: como uma mensagem especial ao "povo". A palavra do religioso repercutiu "agradavelmente, no Brasil inteiro, como se fosse uma clarinada que despertasse o povo para a luta sem tréguas" contra o comunismo. A carta, neste sentido, vem como uma "clarinada", ou seja, como uma bela música, um belo som para os ouvidos do povo brasileiro. Adicionalmente, o deputado defende a "essência evangélica" da democracia, para justificar ainda mais a clarinada do religioso. Assim, conforme o parlamentar pessedista, é perfeitamente legítimo que um arcebispo fale em nome de Deus, do povo e da democracia contra um inimigo comum que é o comunismo. 
Os comunistas são "os mais perigosos inimigos de nossa Pátria, pois desejam cubanizá-la”; são os "mais rancorosos inimigos de Deus os quais procuram expulsar o Santo Nome d'Êle, das páginas da História, criando o Instituto de Ateísmo Científico e até cursos por correspondência para divulgar o ateísmo". São males que, na concepção de Vidigal, devem ser eliminados do Brasil. São razões, portanto, para a luta contra o comunismo: a inimizade que os seus adeptos têm com Deus e o ateísmo declarado com intenções ainda de expulsar Deus das páginas da História. Mais elementos são elencados pelo deputado para a essa nova "cruzada cristã" contra o comunismo, conforme segue:

Dom Oscar despertou a lembrança do clero e dos bons católicos para o seguinte: Jamais poderá a Igreja de Cristo transigir com o comunismo que despoja do homem o sentimento religioso, roubando-lhe a liberdade, negando-lhe a dignidade de pessoa.

O Estado Moscovita exige a abolição completa do Estado Religioso em seus partidários, proclamando haver absoluta incompatibilidade entre a crença de Deus e a aceitação dos princípios comunistas (Apud Georges Goyau, in Dieu chez les Soviets).

O comunismo é a "mais completa negação de Deus" e representa uma "guerra contra tudo o que é divino" (Pio XI, in Divini Redemptoris).

"A Igreja de Cristo não cogita abandonar sem luta o terreno a seu inimigo declarado, o comunismo ateu. Êste combate será continuado até o fim" (Pio XII).

No excerto acima, o deputado utiliza basicamente passagens de autores eclesiásticos que afirmam a total incompatibilidade entre o cristianismo e o comunismo. Iniciada pelo arcebispo de Mariana, dizendo que "jamais poderá a Igreja de Cristo transigir com o comunismo", tendo em vista que o segundo "rouba" do homem a "liberdade" e lhe "nega" a "dignidade de pessoa". Dessa forma, segundo o deputado, o comunismo representa para os seres humanos a "prisão", a "escravidão", por um lado, e a condição "não humana", "não digna" por outro lado. Em consequência disso, a Igreja de Cristo tem a missão de defender os homens contra este "mal". Os demais autores citados denotam a total incompatibilidade entre a religião e o comunismo e que, entre ambas as ideologias, somente a guerra é possível, tendo em vista tratarem de visões de mundo antagônicas. Na sequência, o deputado apresenta uma justificativa para a preocupação política dos religiosos brasileiros:

Amando a sua Pátria como realmente amam, os Exmos. e Revmos. Srs. Arcebispos e Bispos do Brasil naturalmente se preocupam com os problemas políticos no atual momento conscientes de que a política é uma coisa honesta e grave, conforme a expressão de Leão XIII e é aquela ciência civil, como a definiu Santo Tomaz, a qual tem por objetivo procurar o bem comum dos cidadãos o qual é o máximo bem que procuram os homens constituídos em sociedade. Além disso, a política pode tocar em Deus e nos seus altares, pôr suas mãos atrevidas e sacrilegas na Igreja e em seus Ministros e em seus bens, assestar golpes mortais na família, pode escravizar a um povo com leis inhumanas e antihumanas e lançá-lo em nome da liberdade e da democracia, por caminhos da dissolução e morte. 
Em seu mais profundo sentido, a política não pode separar-se da Religião. A razão é óbvia: o fim próximo do Estado é a perfeição exterior da sociedade, porém, uma perfeição de tal natureza que possa ajudar a sociedade a lograr o Bem Supremo.

Os Exmos. e Revmos Srs. Arcebispos e Bispos do Brasil nunca perguntaram uns aos outros o que é mesmo que o Brasil pode fazer por êles. Vivem perguntando, sempre, uns aos outros: o que é que êles podem e poderão fazer pelo Brasil.

Os religiosos brasileiros, segundo o deputado, preocupam-se com a política no Brasil, tendo em vista que o seu objetivo primordial [da política e deles próprios] é "procurar o bem comum dos cidadãos o qual é o máximo bem que procuram os homens constituídos em sociedade”. Se os mais "honestos" e "graves" objetivos da política e da Igreja são os mesmos, política é um assunto que deve ser seriamente tratado também pelos religiosos brasileiros. Claramente, neste ponto, é importante perceber a posição política da própria Igreja Católica, a qual se coadunava com o discurso da "direita" e que, portanto, suspeitava dos propósitos do governo Goulart e dos grupos que, naquela quadra, lhe davam sustentação. A menção que o deputado faz à manifestação de membros do clero está, desta forma, perfeitamente enquadrada nesta lógica da direita brasileira, ou seja, era importante para ela politizar elementos religiosos que, a princípio não deveriam fazer parte do debate político num estado laico.

Outro argumento utilizado como justificativa para a preocupação política dos religiosos é o fato de que a mesma pode ser utilizada para fins "maléficos". Assim, ela pode ser usada para desferir "golpes mortais na família, pode escravizar a um povo com leis inhumanas e antihumanas e lançá-lo em nome da liberdade e da democracia, por caminhos da dissolução e morte". Essas possibilidades, evidentemente, fogem por completo do "bem comum" da política e daí mais uma razão para a intervenção religiosa nesses assuntos, na acepção de Vidigal. Esse argumento subsiste como se os religiosos fossem, de fato, "fiscais" das ações dos políticos para o povo brasileiro, como se cada vez que os políticos tomassem ações contrárias ao "bem comum", estariam lá os religiosos para denunciar tais artimanhas.

Esses argumentos são coroados com uma categórica afirmação do deputado: “[e]m seu mais profundo sentido, a política não pode separar-se da Religião". Dizer isso significa considerar que a "política" é tão-somente uma dimensão da "Religião", ou seja, a "Religião" compreende a "política" como um de seus elementos. Concluir isso significa, por consequência, considerar que os bispos e arcebispos brasileiros têm muito mais autoridade moral, porque são religiosos, para falar corretamente sobre a política e, consequentemente, sobre o "bem comum" como seu fim máximo, do que propriamente os deputados federais, o presidente da República, os políticos em geral. Com isso, o deputado quer "despaganizar" os políticos - mormente os comunistas - e, ao mesmo tempo, "sacralizar" a política, uma vez que os fins do Estado, conforme seu pronunciamento, são os mesmos da Religião: "o fim próximo do Estado é a perfeição exterior da sociedade, porém, uma perfeição de tal natureza que possa ajudar a sociedade a lograr o Bem Supremo”. Finaliza 
parafraseando o ex-presidente norte-americano John Kennedy, dizendo que os religiosos brasileiros, vivem se perguntando o que eles podem fazer pelo Brasil. Tendo em vista a sacralização da atividade política, continua o deputado denunciando as atividades "pagãs" do governo Goulart:

\begin{abstract}
Mas, os comunistas encastelados no Govêrno querem transformar o Brasil em outro belo paraíso da humanidade por meio de uma Reforma Agrária anti-cristã, semelhante àquela que foi um fracasso em Cuba, na China e na Rússia.

Por meio de uma Reforma Agrária que não promoverá o aumento da produção, mas sim, o crescimento da miséria e o desenvolvimento da fome, por meio de uma Reforma Agrária violenta que constitui um atentado contra o sétimo e o décimo mandamento da Lei de Deus, os quais formam o fundamento da propriedade privada, êsses comunistas querem é mesmo desgraçar o Brasil. E, entretanto, cinicamente, declaram que pretendem transformá-lo num belo paraíso da humanidade.
\end{abstract}

Se no excerto anterior, o deputado Vidigal mencionava a justificativa para que os religiosos legitimamente se interessassem pelos assuntos políticos, neste trecho - na mesma direção do argumento de que a "boa política" não passa de um ramo da religião - ele condena o projeto "comunista" de reforma agrária. Inicialmente, o parlamentar caracteriza o governo como um local onde os comunistas estão "encastelados" e que, portanto, todas as ações do governo Goulart, seriam ações implementadas a partir da ideologia comunista, que é anticristã e, nesse sentido, responsável por promover uma "má política". O deputado constrói o argumento de que a reforma agrária pretendida pelo governo federal é uma medida política "anticristã" sem, no entanto, mencionar as razões específicas de tal afirmação. Simplesmente diz que a reforma agrária pretendida não aumentaria a produção agrícola, mas tão-somente a miséria e a fome. Além disso, defende que a referida pretensão do governo contraria os sétimo e décimo mandamentos da "Lei de Deus", os quais, respectivamente obrigam aos católicos (e não ao governo e os comunistas lá encastelados) "não furtar" e "não cobiçar as coisas alheias". Isso quer dizer que as ações do governo são ações contra a "vontade de Deus", promovidas pelo pecado da "avareza", pois retirar terras dos seus proprietários para fins de reforma agrária é ato precedido pela "cobiça das coisas alheias" e que, quando consumado, torna-se furto aos "olhos de Deus". Na concepção dos bispos e arcebispos, conforme o deputado, a reforma agrária é o primeiro passo para "desgraçar o Brasil”. Os passos seguintes são mencionados no excerto a seguir:

As preocupações dos Exmos. Revmos. Srs. Arcebispos, Bispos do Brasil, são de tôdas as horas.

Êles percebem que virá primeiro uma Reforma Agrária, conforme o figurino russo.

Depois virá a Reforma Urbana.

Depois a eliminação completa da iniciativa privada.

E, por fim, a Reforma ou a estatização da família, quando, então, os filhos passarão a pertencer ao Estado e ficarão à disposição do Govêrno que se servirá dêles como de parafusos na engrenagem comunista e fará com que êles se 
levantem contra seus pais quando êstes não concordarem com o Govêrno ou com o Regime.

Foi o que aconteceu na Rússia com aquêle menino que foi constituído herói e erguido à condição de exemplar a ser seguido, visto que denunciou seu pai como um ladrão, somente porque havia levado para casa um pouco de alimento para matar a fome de seus filhos famintos, um pouco mais do que o Govêrno lhe permitia levar.

E o pai foi prêso. E, depois, fuzilado. E o menino mereceu uma estátua e ficou, na história, como modêlo digno de ser seguido pelos outros meninos russos.

Que belo paraíso da humanidade!.

Conforme o excerto acima, os bispos e arcebispos brasileiros já sabem exatamente os passos que serão tomados pelos comunistas em direção da revolução. Quatro serão as ações na seguinte ordem: "reforma agrária", "reforma urbana", "eliminação completa da iniciativa privada" e "estatização da família". É interessante que a "chave de ouro" revolucionária consista na "estatização da família". Nesse ponto, o deputado menciona o exemplo de um garoto que havia denunciado o próprio pai ao Estado soviético como um criminoso e que, por isso, teria se transformado em modelo a ser seguido pelos demais garotos. Assim, se o projeto "comunista" de reforma agrária de Goulart tivesse êxito, esse então seria o primeiro passo para uma revolução equivalente à russa, a qual teve, como grave consequência anticristã, a estatização da família. Exarados os argumentos religiosos do deputado oposicionista ao governo Goulart, serão analisados a seguir trechos do pronunciamento do deputado Antônio Carlos Magalhães (UDN/BA): ${ }^{9}$

\section{O SR. ANTONIO CARLOS MAGALHÃES:}

(Para uma comunicação - Sem revisão do orador) - Sr. Presidente, Srs. Deputados, quero lançar meu veemente protesto, em nome da parcela do povo brasileiro que tenho a honra de representar, contra o comício realizado pelo Partido Comunista Brasileiro no Estado da Guanabara e que teve como orador oficial S. Exa. o Sr. Presidente da República. Mas, Sr. Presidente, a própria personalidade do Presidente da República estava ali ferida como a Nação brasileira, porque o Sr. Osvaldo Pacheco, fazendo questão de demonstrar que o Presidente era o seu teleguiado, a todo instante lhe ditava normas e até mesmo frases. O Sr. Presidente da República neste estado em que se encontra, de falta de autoridade, seguia o pelego comunista.

Neste trecho inicial do pronunciamento de Antônio Carlos Magalhães, o deputado protesta contra a ocorrência do "Comício da Central do Brasil", sobretudo em razão de o presidente da República, conforme o parlamentar, figurar como o seu "orador oficial”. Note-se que o deputado está colocando a questão da seguinte forma: se o comício era organizado pelo PCB, por que o presidente Goulart teria sido o seu orador oficial? Era o presidente membro do PCB? Era comunista o presidente? São inferências que, no discurso de Magalhães, indicam que Goulart estava a serviço dos comunistas brasileiros. Além disso, tem de ser levado também em consideração o próprio fato de que o PCB funcionava como uma organização clandestina, visto que foi considerado um partido político ilegal em 1947. Desta forma, o protesto de Magalhães ganha ainda mais força, ou seja, se o 
PCB, uma organização clandestina, organiza um comício e Goulart é considerado o seu orador oficial, o próprio Goulart estaria incorrendo em crime, visto que o presidente da República apoia ações políticas promovidas por uma organização que está à margem da legalidade.

Na sequência do trecho, o parlamentar aponta que o presidente da República não tinha sequer autonomia para o uso da palavra, tendo em vista que "Sr. Osvaldo Pacheco, fazendo questão de demonstrar que o Presidente era o seu teleguiado, a todo instante lhe ditava normas e até mesmo frases". Um presidente da República que era teleguiado por um cidadão de nome Osvaldo Pacheco, ${ }^{10}$ segundo Magalhães, denotava um chefe de Estado sem personalidade para conduzir o país. O deputado continua suas denúncias:

Sr. Presidente, naquele comício, o que mais se fêz foi afrontar esta Casa de representantes do povo e a mim causa profunda estranheza que ainda aqui se levantem vozes hoje para defender êste Govêrno, principalmente o Presidente da República, porque o normal seria que êstes representantes aqui não mais comparecessem, pois o cunhado do Presidente e o próprio Presidente naquele dia não fizeram outra coisa senão pregar a subversão e o fechamento do Congresso Brasileiro.

Se no primeiro trecho do seu pronunciamento, o deputado denunciava a realização de um comício organizado pelo PCB tendo como orador oficial o presidente da República e, além disso, afirmava que a própria palavra de Goulart era ditada por outra pessoa, o que denotava falta de personalidade do chefe de Estado, neste segundo trecho, o tom da denúncia é muito mais grave. No excerto em questão, o deputado acusa diretamente o presidente Goulart e o deputado Leonel Brizola de defenderem em praça pública o fechamento do Congresso Nacional. Portanto, claramente Jango é taxado de golpista. É evidente que a postura política a ser adotada por um presidente da República, no contexto democrático, deve ser no âmbito dos marcos da legalidade. Buscar o fechamento do Congresso Nacional representa um ato de extrema gravidade, posto que ilegal, o que poderia, inclusive, ensejar processos de impedimento contra o presidente Goulart e também contra o deputado Leonel Brizola, nos termos da Constituição Federal de 1946. Na sequência, serão analisados trechos do pronunciamento do deputado federal Laerte Vieira (UDN/SC): ${ }^{11}$

\section{O SR. LAERTE VIEIRA:}

(Sem revisão do orador) - Senhor Presidente, nobres Srs. Deputados, na última sexta-feira, dia 13, em data verdadeiramente azarada, sob as apreensões de todo o País, promoveu-se um comício na Guanabara, onde S. Exa., o Sr. Presidente da República, desempenhando as suas altas funções de Primeiro Magistrado da Nação, se vinculava a uma pregação de caráter ideológico que, segundo o nosso entendimento, é pregação subversiva e contrária ao regime.

Verificamos, Sr. Presidente, a maneira pela qual se procura envolver as Fôrças Armadas em pronunciamentos dessa espécie, encarregando-as de manter no local do comício a ordem e, sob êste pretexto, fazendo-as assistir, com muito vexame para alguns dos seus integrantes, a uma reunião em que se apresentavam inúmeros cartazes de gorilas, cartazes de foice e martelo, pedidos de legalização do Partido Comunista do Brasil etc. 
O deputado udenista inicia seu pronunciamento já denunciando a participação do presidente no Comício da Central do Brasil, uma "pregação de caráter ideológico", o que, na acepção do parlamentar, mesmo sem caracterizar o que para ele significa "ideológico", denota-se, no contexto discursivo, notadamente o caráter negativo da utilização do termo. Tão negativa é a participação do chefe do Executivo no ato em questão que este foi caracterizado pelo deputado como sendo uma “pregação subversiva e contrária ao regime". Como o parlamentar catarinense não explicita o porquê de ser uma "pregação subversiva e contrária ao regime", não dá para saber ao certo se ele está denunciando um "crime de responsabilidade" do presidente da República ou meramente utilizando-se de artifícios retóricos na introdução de sua fala.

É interessante, no entanto, a forma como o deputado coloca, na segunda parte do excerto, uma possível tentativa, por parte dos organizadores do Comício, de envolvimento das Forças Armadas no ato em tela. Com isso, o deputado está buscando afirmar que os "subversivos" queriam "dar o recado" de que as Forças Armadas estariam "envolvidas" com o ato público, o que, pelo contexto do pronunciamento do parlamentar, não passa de uma ação meramente performática do governo. Nesse ponto, o deputado tem razão: havia uma forte pressão contrária de militares de alta patente de todas as Armas contra as ações que Goulart naquele momento buscava intensificar com setores de esquerda e de extrema esquerda. O Comício da Central do Brasil foi um desses atos duramente criticados pelos altos escalões militares. ${ }^{12}$ Na sequência do seu pronunciamento:

Não nos surpreendeu a pregação do Sr. Deputado Leonel Brizola, pois que tem
sido uma constante na atuaçâo dêste político - já não digo parlamentar porque o
que menos S. Ex. ${ }^{a}$ tem sido é um parlamentar - a pregação revolucionária, a
pregação contra o regime. De modo, Sr. Presidente, que se ouviu nessa reunião o
Deputado Leonel Brizola dizer, com todas as letras, que o atual Congresso não
dará mais nada aos brasileiros, que "se os podêres da República não tomam
decisões, as decisões devem ser tomadas pelo povo", que "ao povo se deve
entregar os destinos desta Pátria, pela convocação de uma Constituinte", pela
organização de um congresso que se denomine popular, pela realização de um
plebiscito, pela derrogação do atual Congresso Nacional.

Neste ponto, Laerte Vieira acusa seu colega Leonel Brizola de deixar de cumprir suas funções parlamentares para exercer a “pregação revolucionária, a pregação contra o regime”. Para justificar sua crítica, Vieira enuncia frases que teriam sido pronunciadas por Brizola durante o Comício. Em tais frases, o deputado busca chamar a atenção para o quanto Brizola tem recorrentemente sido um agitador político de esquerda.

Contudo, é pertinente notar o perfil autoritário do próprio acusador, pois o mesmo pinça frases que teriam sido pronunciadas pelo deputado gaúcho como se as mesmas fossem eminentemente perigosas, mas que podem ser lidas justamente sob uma ótica democrática. Veja-se a primeira delas: "se os podêres da República não tomam decisões, as decisões devem ser tomadas pelo povo", pode ter a interpretação nada forçada de que a classe política poderia estar inerte à crise política do 
momento, por exemplo. Tal frase, combinada com a próxima pode sugerir ainda mais um tom democrático por parte de Brizola: "se os podêres da República não tomam decisões, as decisões devem ser tomadas pelo povo", [pois] "ao povo se deve entregar os destinos desta Pátria, pela convocação de uma Constituinte". Entregar os destinos da Pátria ao povo é uma das acepções mais senso comum da democracia, o "poder do povo", ainda mais em se tratando de convocar uma Assembleia Nacional Constituinte para reformar a Constituição de 1946, um expediente amplamente amparado em preceitos e em práticas democráticas. O tom conservador de Vieira condena seu discurso, altamente impopular. Continua o pronunciamento:

Do comício Srs. Deputados, V. Ex ${ }^{\text {as }}$. Naturalmente observaram o destaque que deram à palavra do representante do CGT. Falou em último lugar, não teve seu tempo limitado, dispôs de maior espaço do que parlamentares ou chefes de Executivos estaduais que lá compareceram, pregou as reformas a seu modo, impôs ao Presidente da República o registro de todos os partidos, vale dizer, a legalização do Partido Comunista, e disse também, como uma situação que vem incomodando muito as esquerdas dêste País que o Presidente da República precisava definir-se - ou o Presidente continua com a política de conciliação, ou o Presidente realiza as chamadas reformas de base.

Neste excerto, o deputado fala, de forma mais direta, sobre a primazia da participação do Comando Geral dos Trabalhadores. Inicia reclamando que seu representante falou por último no Comício e por mais tempo do que os parlamentares ali presentes, o que, na visão de Laerte Vieira, soava "errado", tendo em vista que os deputados eram personalidades mais importantes que o representante do CGT, como fica subliminar em sua fala. É de se lembrar, entretanto, que o Comício foi organizado pelo próprio CGT e que os deputados presentes fizeram uso da palavra na condição de convidados. Dessa forma, parece um exagero o deputado condenar a forma como o CGT organizou as falas dos oradores no evento.

Por outro lado, parece interessante ressaltar a forma como o parlamentar se referiu à presença do presidente da República no ato. Ela é similar à forma como o deputado Antônio Carlos Magalhães fez referência a Goulart no trecho analisado acima. Ambos dão a entender que o presidente da República tinha uma personalidade fraca. No caso de Vieira, pode ser introduzido ainda mais um elemento: o presidente era passivo de ameaça por parte do CGT. Isso fica claramente estampado no momento de seu pronunciamento em que o deputado afirma que o representante do CGT “impôs ao Presidente da República o registro de todos os partidos, vale dizer, a legalização do Partido Comunista".

Fica ainda evidente o tom ameaçador que o CGT se referiu a Goulart, segundo o deputado, quando o mesmo afirmou que teria o representante do CGT afirmado que Jango deveria optar ou "pela política de conciliação" ou pelas "reformas de base", como se ambas propostas fossem necessariamente antagônicas, uma vez que o presidente da República em sua fala naquele evento 
propôs basicamente reformas de base precedidas de uma reforma constitucional, o que pode ser visto como uma política de conciliação, visto que isso requereria necessariamente passar pelo âmbito do poder legislativo federal. $\mathrm{Na}$ sequência, passar-se-á à análise de trecho do pronunciamento do deputado Maurício Goulart (PTN/SP): ${ }^{13}$

Ora, Sr. Presidente, Srs. Deputados, o que estamos a ver de certo modo a essa parte, e cada dia com intensidade, é a reiteração de movimentos que, com o objetivo de solapar as instituições, procuram desmoralizar o Parlamento perante a opinião pública. E o que aflige, espanta e estarrece é que êsses movimentos, cujas raízes, ultrapassando as fronteiras pátrias vão buscar orientação [...] em concepções de vidas estranhas a nossa índole, são liderados por homens e órgãos inseridos na órbita do Poder Executivo.

Já agora, aliás, Sr. Presidente e Srs. Deputados, como se tornou patente pelo comício do dia 13, é o próprio Chefe do Govêrno que assume o ostensivo comando e acoroçoa a campanha de achincalhe às instituições, investindo ou permitindo que invistam, em praça pública, em sua presença, contra a dignidade do Congresso Nacional.

A Constituição que jurou obedecer e à obediência de cujos preceitos deve o exercício do mandato presidencial [...] consentindo, com complacente sorriso, que a televisão levou e está levando para as populações de todo o País, que auditório convocado de todo o território nacional para ouví-lo, reclama-se, em brados repetidos e bem ensaiados, o fechamento do Congresso.

Neste longo trecho, Maurício Goulart denuncia uma "estratégia" de desmoralização com o objetivo de posterior fechamento do Congresso Nacional. Trata-se, segundo o deputado, de uma estratégia conduzida por "movimentos" que, mesmo sem serem por ele nomeados, podem ser identificados, pois são os mesmos que participaram do Comício da Central do Brasil. Os objetivos desses movimentos são claros: "solapar as instituições, [...] desmoralizar o Parlamento perante a opinião pública".

A denúncia toma contornos ainda mais graves quando o parlamentar alia a figura de João Goulart com tais movimentos. O presidente é acusado de "acoroçoar", ou seja, encorajar a ação desses setores, ao mesmo tempo em que se torna parceiro dos mesmos. Assim, a estratégia de desmoralizar para após fechar o Congresso Nacional é também uma tarefa do presidente da República. Além de ser uma denúncia, que uma vez constatada sua veracidade, estaria Goulart, do ponto de vista penal, incorrendo em crime de responsabilidade e, portanto, passível de impedimento de suas funções públicas e posterior responsabilização criminal.

Já, do ponto de vista político, isso representa claramente a formação de dois grupos antagônicos, ${ }^{14}$ a saber: de um lado, os movimentos defensores do fechamento do Congresso Nacional e, de outro lado, os grupos interessados em manter as casas legislativas em pleno funcionamento. O que o deputado busca é identificar Goulart como pertencente ao grupo favorável ao fechamento do Congresso. O tom antagônico é ainda mais agravado no discurso do deputado na seguinte passagem: 
Não, Sr. Presidente: não Senhores Deputados: a radicalização explosiva, que aí está, já agora ameaçando interromper o processo democrático no Brasil, essa radicalização não fomos nós que a criamos, apesar dos acres entusiasmados com que defendemos nossos pontos de vista, nossas preferências ideológicas. Tampouco criaram essa radicalização, com o caráter de que ela hoje se reveste, os estudantes brasileiros, com seus excessos juvenis; tampouco, a criaram os trabalhadores das cidades e dos campos, reunindo-se em assembleias e saindo para as ruas, na defesa de melhores condições de vida. Criou-a, acaba de institucionalizá-la, o Sr. Presidente da República, abrindo um fôsso, já agora quase impossível de transpor entre o Poder Legislativo e o Poder Executivo.

Neste excerto, o deputado afirma que a situação política naquele instante era de uma "radicalização explosiva" que ameaçava "interromper o processo democrático no Brasil". Assim, conforme sua leitura do momento, o processo de formação de dois discursos antagônicos estava dado e parecia ser esse um caminho sem volta, uma radical exclusão entre dois projetos inimigos, de modo que uma "guerra", portanto, já ocorria naquele instante.

No excerto anterior, o deputado afirmava que Goulart fazia parte - juntamente dos movimentos que lideraram o Comício da Central do Brasil - de um grupo que tinha como estratégia desmoralizar para posteriormente fechar o Congresso Nacional. Ocorre que no presente trecho do pronunciamento de Maurício Goulart, o presidente não é tido simplesmente como um partícipe, ou mesmo aquele que passivamente permitia os excessos dos movimentos da esquerda radical. Neste ponto, Jango passa a ser o protagonista de um momento radicalmente antagônico, o "criador" e “institucionalizador" de uma crise "agora quase impossível de transpor entre o Poder Legislativo e o Poder Executivo". É interessante perceber que tanto os níveis atingidos pela acusação do deputado alteram como os artífices da mesma. Antes foram nomeados os "movimentos" e Goulart era tãosomente um membro. Agora, a crise não tem mais origem exterior às instituições políticas, mas é interna às mesmas, uma guerra antagônica entre dois inimigos no interior do próprio Estado: os poderes Executivo e Legislativo.

\section{A defesa de Goulart diante da sua manifestação na Central do Brasil}

Apresentados os principais sentidos produzidos por deputados alinhados à direita do espectro político e, portanto, contrários a Goulart e ao seu projeto de reformas de base, neste momento, serão apresentados os argumentos produzidos pelos deputados defensores da política reformista de Jango. Assim, serão analisadas passagens significativas de seus pronunciamentos nas mesmas seções legislativas em que os deputados de direita acusaram o governo. $\mathrm{O}$ primeiro pronunciamento a ser analisado é do deputado João Veiga (PTB/AM): ${ }^{15}$

\section{O SR. JOÃO VEIGA}

(Para uma comunicação - Sem revisão do orador) - Sr. Presidente, embora em Brasília na sexta-feira passada, ouvi a fala do Presidente da República. Houve, como é claro e natural, muita pessoa aborrecida; notamos mesmo que esperneou a 
Oposição nesta Casa. Sei ler e escrever - é o que parece - e, analisando detidamente o que o Presidente da República disse na praça na Guanabara, não vislumbrei, não lobriguei sequer heresia ou atentado direto à democracia em nossa Pátria.

O início do pronunciamento do deputado do Amazonas serve para afirmar que, segundo sua análise, o presidente da República não cometeu qualquer "heresia ou atentado direto à democracia em nossa Pátria”, acusação uníssona no discurso da oposição. Tal constatação é fruto, como ressalta o petebista, de uma detida análise do teor do pronunciamento de Jango. Afirma que o pronunciamento em questão "aborreceu muita gente" e, em seguida, elencou as razões de tais aborrecimentos:

Disse bem o Sr. João Goulart: "é a época das reformas", e de maneira urgente para que se saia de estruturas obsoletas e arcaicas. É muito fácil, como dizia Nietszche, atirar-se uma pedra em um poço. Quando se atira uma pedra em um poço é muito difícil retirá-la, atingindo ela o fundo do poço. É muito melhor salvar o Brasil agora que esperar que caia em abismo profundo, insondável, porque sua salvação, sua retirada será dificílima. Parabéns Senhor Presidente João Goulart. Agindo V. Exa. como está agindo, dando razão e dando atenção aos reclamos do povo, estará agindo muito bem.

O excerto apresenta o tema das reformas de base como central. Inicia com uma frase atribuída a Goulart: "é a época das reformas". Aborda tais reformas sob dois aspectos: primeiramente como necessárias para evitar que o Brasil caia no "fundo do poço" e, por segundo, as mesmas como fruto legítimo dos "reclamos do povo".

Assim, por um lado, o primeiro aspecto diz respeito à centralidade das reformas nos cenários político e econômico. Reformar vários setores, de acordo com as reformas de base, por exemplo, as reformas agrária, urbana, universitária não se trata de mero expediente político de "atualização" de “estruturas obsoletas e arcaicas". A questão colocada pelo deputado é que tais estruturas obsoletas e arcaicas, num momento futuro, serão responsáveis por jogar o Brasil num abismo "profundo" e “insondável”, ou seja, de onde não se pode encontrar o fundo ou o limite. Assim, o caráter das reformas não é meramente uma adequação social de um país com estruturas obsoletas: trata-se antes de uma ação política que tem um caráter salvacionista. Nesse sentido, em se tratando de reformas nesse nível e tendo o presidente como seu maior defensor, é de se denotar, pelo contexto discursivo, que se o presidente da República conseguir o seu intento de promover as reformas prometidas, ele será reconhecido como um salvador nacional, aquele que evitará a queda insondável do Brasil para o fundo do poço.

Por outro lado, as reformas fazem parte dos "reclamos do povo". Nesse ponto, é interessante perceber que o presidente da República não está tomando uma atitude baseada em sua convicção pessoal apenas, ou forjada por um único partido ou ideologia política. O presidente é visto aqui como aquele que é capaz de ouvir e de perceber os reclamos do povo, ou seja, ele se coloca ao lado 
do povo como um de seus integrantes. Aqui a formação do "povo" é assaz interessante, tendo em vista que o deputado deposita em Goulart a condição de seu intérprete, como o responsável pela articulação das demandas populares. Nesse sentido, deputados, líderes políticos e militares, contrários às reformas de base, são relegados à condição de adversários ou mesmo de inimigos políticos, pois que constituem um grupo que deve ser combatido, sob pena de as reformas não se realizarem. A seguir, será analisado trecho do pronunciamento do deputado Ortiz Borges (PTB/RS), ${ }^{16}$ em aparte ao discurso do deputado Laerte Vieira (UDN/SC) já aqui tratado:

O Sr. Ortiz Borges - O meu aparte é apenas para dizer, eminente Deputado Laerte Vieira, que me custa crer que tenha $\mathrm{V}$. $\mathrm{Ex}^{\mathrm{a}}$ a coragem de vir à tribuna para dizer, por exemplo, que o comício de sexta-feira foi anti-democrático, que o comício foi contra o regime democrático neste País. E isto porque, eminente colega, nunca se viu tanta gente reunida em praça pública em tôda a Nação, para tratar de assuntos de alto interesse popular. Todos os oradores que se fizeram ouvir naquela ocasião disseram aquilo que precisava ser dito, interpretando a vontade popular. $\mathrm{O}$ Presidente da República, no seu pronunciamento, pregou a reforma de nossa Constituição, pregou a reforma eleitoral, pregou a reforma universitária [...] e sobretudo, eminente Deputado, interpretou a vontade popular.

Mas com o que V. Exa s não se conformam é com o regime do povo para o povo e pelo interêsse do povo. V. Ex ${ }^{\mathrm{a}} \mathrm{s}$ pregam o regime do privilégio. V. Ex ${ }^{\mathrm{a}} \mathrm{s}$. desejam que se pregue uma democracia antipovo, uma democracia anti-reforma, uma democracia contra os sindicatos.

Nota-se, na passagem acima, que o deputado Ortiz Borges, a exemplo do pronunciamento do deputado João Veiga, constituiu duas posições políticas antagônicas, as quais podem ser chamadas, tomando-se o contexto de sua fala, uma de "popular" e a outra de "antipopular". Assim, a posição política "popular" é formada pelos movimentos organizadores do Comício da Central do Brasil, articulados ainda com políticos de esquerda e com o próprio presidente da República. O discurso em questão tem o mérito, segundo o deputado, de reunir o povo em praça pública. Suas lideranças são tidas como aquelas que efetivamente sabem interpretar os anseios populares: "todos os oradores que se fizeram ouvir naquela ocasião disseram aquilo que precisava ser dito, interpretando a vontade popular". Os grupos articulados pelo discurso "popular" são, ainda, defensores das reformas de base e têm o presidente da República conjunturalmente como o seu principal prócer: “o Presidente da República, no seu pronunciamento, pregou a reforma de nossa Constituição, pregou a reforma eleitoral, pregou a reforma universitária [...] e sobretudo, [...] interpretou a vontade popular".

Já, o segundo grupo, chamado de "antipopular" é discursivamente construído como sendo antagônico ao "popular" segundo o pronunciamento do deputado gaúcho, no sentido da noção de antagonismo de Laclau e Mouffe (1985) já aqui apresentada. Representa setores que não querem ouvir o povo, que defendem o regime do privilégio: "uma democracia antipovo, uma democracia 
antirreforma, uma democracia contra os sindicatos". Em outro momento, Ortiz Borges (PTB/RS), ${ }^{17}$ segue tratando sobre o Comício da Central do Brasil:

Foram duzentas mil pessoas, de tôdas as camadas - operários, estudantes, intelectuais, donas de casa, homens, mulheres e crianças - que, sintonizando com as aspirações gerais do povo brasileiro compareceram ao comício no dia 13 do mês corrente.

Disseram os democratas da direita, hoje representados na tribuna pelo Deputado Laerte Vieira, que o comício da Guanabara foi um ato atentatório ao regime democrático, que o que se quis foi apenas ferir a Constituição e denegrir o regime. [...] Ora conspirar contra o regime seria, isso sim, não poder conversar francamente nas grandes praças públicas. Como disse um dia o poeta, "a praça é do povo como o céu é do condor". Ferir a Constituição seria, isso sim, a conspiração surda, macia, das antessalas dos gabinetes; seria, isso sim, $\mathrm{Sr}$. Presidente, os conchavos que muitas vêzes se fazem como se diria na linguagem do Rio Grande, por baixo do poncho; seria, isso sim, Sr. Presidente, aquilo que se proclamou ontem, por exemplo e que chegou a andar de bôca em bôca nesta Casa: o atentado que se pretende perpetrar contra o Presidente da República, querendo impedi-lo de governar. Isto, sim, seria ato atentatório às liberdades democráticas; isto sim, seria ferir a Constituição, seria denegrir a democracia.

O presente excerto é constituído basicamente por três momentos principais. O primeiro diz respeito aos sentimentos populares que estariam sendo captados, na sua plenitude, pelos movimentos e sujeitos políticos que participaram do Comício da Central do Brasil. O segundo momento diz respeito à contestação que o deputado Ortiz Borges faz em relação à acusação de seu colega Laerte Vieira de que a referida reunião pública havia sido um ato atentatório à democracia. O terceiro momento principal do excerto, que é na verdade um desdobramento do segundo, diz respeito à denúncia que o deputado faz na tribuna de que é a direita quem realmente busca golpear os poderes políticos de Goulart e não ao contrário como argumentava o deputado Vieira. Assim, faz-se necessário o desdobramento dos segundo e terceiro momentos do trecho selecionado.

Desta forma, o segundo momento refere-se à defesa de Ortiz Borges em relação à legitimidade da reunião pública de 13 de março em contradita ao seu colega Laerte Vieira. É evidente que uma reunião popular pacífica como aquela se constitui num expediente democrático, calcado sobremaneira nos princípios de liberdade de opinião e de reunião. Nesse sentido, o deputado gaúcho visa à desqualificação do argumento de Vieira, a partir desses preceitos democráticos consignados na seguinte passagem do seu pronunciamento: "conspirar contra o regime seria, isso sim, não poder conversar francamente nas grandes praças públicas". Ocorre que o argumento de Laerte Vieira, condenando de antidemocrático o ato público, não está baseado na condenação dos princípios democráticos de opinião e de reunião. Vieira argumenta que a suposta ilegalidade do Comício estaria assentada no teor dos pronunciamentos dos seus oradores, como visto anteriormente na análise de trechos de seu discurso, pronunciamentos, segundo o deputado oposicionista, esses sim, 
que estariam atentando contra a democracia, basicamente por condenarem a ação e proporem, por consequência, o fechamento do Congresso Nacional.

O terceiro momento do excerto em questão diz respeito a uma denúncia do parlamentar gaúcho, não assentada em elementos comprobatórios, de que quem, na verdade, estaria buscando golpear o poder político no Brasil era a direita e não Goulart. Busca o deputado gaúcho qualificar a ação dos supostos golpistas de "antipopular", tendo em vista estar sendo tramada "surda, macia, das antessalas dos gabinetes". Segundo Borges, a ameaça de golpe estaria passando de "boca em boca" no parlamento brasileiro naquela ocasião. E conclui em resposta à Vieira: "isto, sim, seria ato atentatório às liberdades democráticas; isto sim, seria ferir a Constituição, seria denegrir a democracia”. O argumento esquerdista em relação ao golpe que estaria sendo intentado pela direita ganha ainda mais força nas palavras do deputado Mário Maia (PTB/AC), ${ }^{18}$ o qual estabelece o "perfil" dos golpistas:

Sexta-feira última, 13 do mês em curso, o Brasil inteiro ouviu com atenção e patriotismo a fala de seu presidente. Como não poderia deixar de ser, houve os que gostaram e houve os que não se conformaram. Felizmente, para nossa tranquilidade, o número dos que se desencantaram compreende a estreita faixa dos agitadores moralistas, dos desordeiros de gabinete, dos manipuladores de intrigas, dos forjadores de boatos, dos maquinadores de golpes frustrados, enfim, desse pequeno enxame de arapuás que zunzunzeiam em volta da velha colmeia dos privilégios, na perene festa da intolerância e da ociosidade supérflua.

Neste excerto, o deputado petebista estabeleceu o perfil das lideranças e dos políticos contrários à manifestação na Central do Brasil. Partindo do pressuposto de que o evento retratou um momento de encontro de Goulart com o povo brasileiro - "o Brasil inteiro ouviu com atenção e patriotismo a fala de seu presidente" - o parlamentar defendeu que os contrários à manifestação eram, na verdade, contrários ao povo brasileiro, contrários ao encontro dos políticos com a população. Assim, os golpistas se incomodavam com a popularidade do presidente da República e, para manterem seus "privilégios" e ociosidade supérflua, conspiravam contra as instituições democráticas.

\section{A resposta da direita: a Marcha da Família com Deus pela Liberdade}

Nesta seção, serão analisados os pronunciamentos dos deputados federais referentes ao evento ocorrido em São Paulo, em 19 de março de 1964, que fícou conhecido como a "Marcha da Família com Deus pela Liberdade”. Em relação ao Comício da Central do Brasil - promovido pelo CGT e por outros movimentos populares e de esquerda, além do apoio de lideranças políticas, sobretudo vinculadas ao PTB e ao clandestino PCB - pode-se afirmar que a "Marcha da Família", representou um contraponto de peso da "direita" brasileira, uma vez que existem registros, como os do Jornal “O Estado de São Paulo", da presença de 300 mil manifestantes, ou seja, o dobro do que foi 
contabilizado de participantes do Comício da Central do Brasil. ${ }^{19}$ A "Marcha" contou com a presença do presidente do Senado Federal, Auro de Moura Andrade, e do governador da Guanabara, Carlos Lacerda.

Contrariamente ao debate ideológico acirrado que o Comício da Central do Brasil provocou no âmbito da Câmara dos Deputados, a "Marcha da Família com Deus pela Liberdade" não foi contestada enfaticamente pelos parlamentares da "esquerda". Aliás, o episódio não teve a grande repercussão que se poderia esperar nos pronunciamentos dos deputados da oposição, no sentido de eles afirmarem que o povo não estaria ao lado de João Goulart, como afirmaram anteriormente os deputados de situação após o Comício de 13 de março.

A primeira manifestação parlamentar em defesa da "Marcha da Família" que consta nos anais do Diário do Congresso Nacional é a do deputado Antônio Sílvio da Cunha Bueno (PSD/SP), ${ }^{20}$ o principal articulador do evento:

\section{O SR. CUNHA BUENO:}

(Para uma comunicação - Sem revisão do orador) - Senhor Presidente, continua ecoando em todos os quadrantes do País a extraordinária demonstração de civismo oferecida na semana passada por 500 mil brasileiros que vieram à praça pública trazer a mensagem de repúdio do povo paulista às tentativas de comunização de nossa Pátria, tentativas que, infelizmente, ao invés de serem energicamente repelidas pelo poder público, têm contado com a colaboração e o prestígio de inúmeros setores governamentais. A "Marcha da Família com Deus pela Liberdade", convocada pelas entidades que congregam as mulheres de São Paulo foi sem dúvida uma demonstração inequívoca de fé.

No início de seu pronunciamento, o deputado paulista enuncia o "extraordinário civismo" de “500 mil brasileiros” que participaram da manifestação. Cita ainda a motivação principal da "Marcha", ou seja, um "repúdio do povo paulista às tentativas de comunização de nossa Pátria". Tais tentativas de "comunização" estariam sendo alimentadas inclusive pelo governo federal, na ótica de Bueno.

No entanto, o que parece mais relevante neste trecho, do ponto de vista da análise política, é exatamente o que o deputado meramente mencionou sem dar maior destaque. Tratam-se das entidades promotoras do evento, como a CAMDE (Campanha da Mulher pela Democracia). A "Marcha da Família" gerou de imediato dois trunfos importantes para a direita brasileira. O primeiro deles, a inegável multidão que compareceu ao ato, mais numerosa se comparada àquela presente ao Comício da Central do Brasil. O segundo e mais importante: a multidão era formada, sobretudo, por mulheres, não filiadas oficialmente a quaisquer partidos políticos ou movimentos sociais, portanto, sem uma declarada definição ideológica, como a dos movimentos que participaram da concentração de 13 de março. Para todos os efeitos políticos, eram simplesmente "mães de família" que protestavam contra o governo João Goulart e esse fato, por si só, teve um peso político devastador, pois foi um dos elementos que teria encorajado os golpistas de 31 de 
março. "Mães de família" pedindo "paz", “democracia”, contrárias à "comunização do país" representavam, independentemente dos políticos direitistas que patrocinaram o evento, como Carlos Lacerda, Ademar de Barros e Auro de Moura Andrade, um duro golpe na credibilidade e na popularidade do governo Goulart. Seguindo aquele senso comum de que "somente um filho rebelde contestaria a autoridade de uma mãe de família, porque somente uma mãe sabe o que é bom para os seus filhos", como lidar com isso politicamente para uma esquerda que tinha um discurso absolutamente político? Afinal de contas, no dito popular, “mãe é mãe”. Segue o deputado:

O meio milhão de almas que saiu às ruas, espontaneamente, para acompanhar,
disciplinadamente, aquela festa cívica não tinha em mente qualquer preocupação
de ofender os poderes constituídos. Muito pelo contrário, Senhor Presidente. A
"Marcha da Família com Deus pela Liberdade", constitui, na realidade, um
movimento de paz, um apêlo para que os homens mais responsáveis pelos destinos
do País aproveitem êste episódio, esta oportunidade que talvez seja a última antes
que o País se desgrace com a deflagração de uma guerra civil.

Neste excerto, o deputado paulista visa ao enfoque, inicialmente, de que a "Marcha" tenha sido um movimento popular "espontâneo", "disciplinado" em nome da "paz" e que representou um "apelo" para o entendimento entre os homens públicos do país. O parlamentar dá a entender que o evento, uma vez "espontâneo", portanto, representava uma sincera preocupação do povo com relação aos destinos políticos do Brasil. Note-se que a situação política no país era diretamente enfocada como sendo gravíssima, tendo em vista que a "Marcha" seria a "última oportunidade" de reconciliação "antes que o País se desgrace com a deflagração de uma guerra civil". Na sequência do pronunciamento, o deputado paulista compara a "Marcha" com o "Comício da Central do Brasil":

\begin{abstract}
Acreditamos, Sr. Presidente, que a Presidência da República deve estar profundamente chocada com essa manifestação de fé nos destinos do Brasil. Fazendo aqui um paralelo com a concentração do dia 13, realizada no Rio de Janeiro, com a presença do Chefe da Nação e o apoio dos Ministérios Militares, com as facilidades de transporte abundante oferecido pelos cofres públicos e com a extraordinária publicidade, além de uma poderosa cadeia de televisão, aquêles que prepararam com tanto cuidado o comício do dia 13 devem estar surpresos com as brasileiras de São Paulo que, ao invés de usar tanques de guerra preferiram arrimar seu movimento de afirmação democrática na fôrça moral dos rosários. Sabe V. Ex ${ }^{a}$., Senhor Presidente, que esse movimento cívico em cadeia está explodindo em tôdas as capitais e nas principais cidades do interior do Brasil. Mesmo aqui em Brasília, Capital da República, as mulheres já se reúnem para promover, no próximo dia 10, no período da tarde, a Marcha da Liberdade, que se destina principalmente a prestigiar todos os membros do Congresso Nacional. No próximo dia 2, na cidade do Rio de Janeiro, na Esplanada do Castelo, também as brasileiras daquela cidade do Brasil vão dar demonstração de sua decisão inabalável de fazer todo o possível para que realmente o País encontre seus verdadeiros destinos.
\end{abstract}

A comparação realizada pelo deputado, a qual realmente dava motivos para a Presidência da República ficar "profundamente chocada", refere-se ao preço pago por cada um dos movimentos para alcançar o sucesso de público em suas concentrações. Em relação ao Comício da Central do Brasil, este contou com a "presença do Chefe da Nação e o apoio dos Ministérios Militares, com as 
facilidades de transporte abundante oferecido pelos cofres públicos e com a extraordinária publicidade, além de uma poderosa cadeia de televisão”, ou seja, aduz o deputado que o seu sucesso se deveu sobremaneira ao forte apoio institucional recebido. Neste particular, o deputado é ainda irônico, quando faz referência ao "transporte abundante oferecido pelos cofres públicos", o que inclusive sugere o emprego ilegal da máquina estatal para fins político-partidários. Mesmo assim, na análise do deputado do PSD, o Comício do dia 13 reuniu somente a metade dos membros da "Marcha", ou seja, 150 mil manifestantes.

Já a "Marcha da Família com Deus pela Liberdade", um movimento "espontâneo", como mencionado pelo parlamentar no excerto anterior, não teve o apoio institucional da Presidência da República e dispensou os "tanques de guerra", referindo-se à presença de membros das Forças Armadas no Comício da Central do Brasil. Em troca, "preferiram arrimar seu movimento de afirmação democrática na fôrça moral dos rosários". Rosários ao invés de tanques, religião ao invés de política. As mulheres foram "rezar" pelo Brasil, pela paz e pela democracia: uma imagem que é muito difícil de apagar, pois que muito marcante, num cenário político radicalizado como aquele. Além disso, outras "marchas", como segue no excerto, já tinham datas para ocorrer em outras capitais brasileiras, como no Rio de Janeiro e em Brasília. Nesse contexto, merece destaque especial a concentração que estava sendo programada para Brasília. A "Marcha da liberdade" teria como objetivo principal "prestigiar todos os membros do Congresso Nacional”, numa clara declaração de guerra aos auspícios de uma pequena parcela radical da esquerda brasileira que defendia, inclusive, o fechamento do Congresso Nacional.

Dessa forma, pode-se afirmar que o deputado tinha plena convicção de que a "Marcha" havia rendido muito mais frutos do que o Comício organizado pelo CGT e demais movimentos de esquerda. A propalada popularidade de João Goulart já não era tão convincente assim: seus contrários eram também numerosos. Esse dado representa um indicativo muito forte de que um possível golpe de direita poderia não ser tão traumático à população como um todo.

Os sentidos políticos produzidos pela "Marcha da Família com Deus pela Liberdade” eram poderosos demais para serem livremente combatidos como foram aqueles produzidos pelo Comício da Central do Brasil. Os significados articulados na "Marcha", a princípio, não políticos, como “mães de família", "paz”, “ordem”, "religião”, eram caros ao imaginário popular dos brasileiros e, portanto, difíceis de ser contestados do ponto de vista discursivo. Disputar sentidos contra os acima elencados seria disputar contra o "sagrado" e, portanto, tornar-se "profano". Assim, o deputado federal Benedito Cerqueira (PTB/GB), ${ }^{21}$ de forma muito moderada, contraditou o discurso de Cunha Bueno: 


\section{O SR. BENEDITO CERQUEIRA:}

(Para uma comunicação) (Sem revisão do orador) - Sr. Presidente, Senhores Deputados, temos ouvido, nestes últimos dias, ainda, os comentários pró e contra as concentrações que se fazem em nosso País.

Sr. Presidente, para a satisfação dos homens - se pudéssemos assim chamar considerados de esquerda nesta Casa, não vimos nenhum dêles vir ao microfone para condenar a grande concentração que se realizou em São Paulo, em defesa da lei da Constituição e da ordem.

Isto para nós é motivo de alegria, porque demonstra que, de nossa parte, não há nenhuma intolerância. Também, Sr. Presidente, em São Paulo, durante os preparativos para aquela concentração, nenhum dirigente sindical, nenhum dirigente político, quer do P.T.B., quer do Partido Socialista ou de outros partidos coligados, ameaçou ou tomou qualquer atitude a fim de impedir que fôsse a mesma realizada. Assim desejamos que ocorra da outra parte.

Neste excerto, o deputado da Guanabara, aliado de Goulart, se vê obrigado a concordar que, em São Paulo, houve uma "grande concentração" “em defesa da lei, da Constituição e da ordem”. Admite a força popular reunida naquele protesto contra o governo federal, com certo constrangimento, uma vez que para um político de esquerda - que normalmente se vale de um discurso tido como popular para balizar a sua atuação política - aquela multidão nas ruas da capital paulista era um fato político a se respeitar. Tendo por base esse argumento, Cerqueira afirma que a "Marcha da Família" ocorreu sem maiores problemas, tendo em vista o caráter democrático que possui a esquerda brasileira: "nenhum dirigente sindical, nenhum dirigente político, quer do P.T.B., quer do Partido Socialista ou de outros partidos coligados, ameaçou ou tomou qualquer atitude a fim de impedir que fôsse a mesma realizada". Tal referência foi feita pelo deputado, tendo em vista os boatos das tentativas de impedimento da realização do Comício da Central do Brasil por membros de grupos direitistas, além de incidentes violentos ocorridos, naquele mesmo período, na Faculdade de Direito de São Paulo e em Minas Gerais. Mesmo considerando a "Marcha da Família" um acontecimento político relevante, o deputado petebista apresenta uma única crítica ao evento como segue:

Não é bom mobilizar senhoras da sociedade para virem com os sagrados rosários
impedir que o povo vá à praça pública ou recintos fechados pregar suas ideias.
Não é bom mobilizar estudantes e jovens trabalhadores, também ligados a cultos
religiosos, para tentar impedir essas manifestações populares. O povo deve
manifestar-se em praça pública como desejar. Os que não quiserem ouvir, que lá
não compareçam. Quanto aos outros, se for do seu agrado, que compareçam.
Assim estaremos praticando realmente a democracia.

O deputado, neste trecho, utiliza o argumento de que a "Marcha da Família com Deus pela Liberdade" foi uma estratégia da direita conservadora brasileira visando inibir a esquerda e o governo federal de promoverem manifestações em favor das reformas de base. É interessante, neste particular, verificar a imagem que o parlamentar cria acerca do fato. Ele afirma que "senhoras da sociedade [...] com sagrados rosários" e "jovens trabalhadores [...] ligados a cultos religiosos" são 
"mobilizados", ou melhor, são "usados" como "massa de manobra" para impedir que "o povo" saia às ruas para "pregar suas ideias". Mesmo considerando o fato de que os setores que promoveram o Comício da Central do Brasil podem ser considerados propriamente políticos (sindicatos e partidos, principalmente) e que, portanto, se diferiam da "sociedade cristã" que estava à frente da "Marcha" e que, em si, não se configura num movimento político, ainda sim tem de ser considerada esta manifestação como legitimamente política, tendo em vista os marcos de um Estado democrático de direito, num momento de constantes conturbações e de episódios que mobilizaram a sociedade brasileira como um todo. Na sequência, serão apresentados mais argumentos da direita parlamentar brasileira, a partir do pronunciamento do deputado federal Herbert Levy (UDN/SP): ${ }^{22}$

Porque o que é preciso dizer ao povo, nesta altura, é uma verdade simples: a onda demagógica calculadamente lançada pelo Presidente da República constitui mera cortina de fumaça para encobrir a única coisa que o preocupa permanentemente, a êle e ao seu cunhado: a permanência no poder.

Já agora a opinião pública não encara as denúncias que há dois anos vimos insistentemente formulando quanto aos propósitos verdadeiros que animam o $\mathrm{Sr}$. João Goulart como simples tomada de posição oposicionista. Porque, desde o comício subversivo de 13 de março, desafivelaram-se as máscaras e o Presidente da República e seu cunhado já se julgam em condições de descobrir os seus verdadeiros propósitos.

O excerto inicia com uma constatação que o deputado paulista deseja que o leitor do seu tempo concorde. Toda a onda de radicalismo político e de demagogia que o presidente da República estava fazendo naquele momento já estava sendo denunciada há, pelo menos, dois anos pela oposição. Tais denúncias, conforme o parlamentar udenista, não eram percebidas na sua integralidade, uma vez que passavam como meras tomadas de posição oposicionista. Dessa forma, o que o deputado busca que seja concluído, e que é o verdadeiro propósito do presidente da República e de seu cunhado, Leonel Brizola, é a “permanência no poder”. Tal permanência no poder - apesar de não ter sido dita por Levy textualmente neste excerto - implicitamente somente poderia ser alcançada se fosse impetrado um golpe por parte de Jango e Brizola. Nesse sentido, o Comício da Central do Brasil ou, nas palavras do deputado, "o comício subversivo de 13 de março", revelou a intenção de Goulart de permanecer no poder, qualquer que fosse a forma de conquista deste intento. Continua o parlamentar, esmiuçando mais ainda os objetivos do presidente:

Nos mínimos detalhes essa manifestação foi reveladora: na ousadia com que se desafiou o Congresso a pedra no caminho para a ditadura que é preciso remover a qualquer custo; nos recursos escandalosamente mobilizados, inclusive os ônibus gigantes das emprêsas de economia mista, desde a Fábrica Nacional de Motores à Cia. Siderúrgica Nacional, à Petrobrás e até mesmo os da Universidade Rural; na desenvoltura com que a partir das 16 horas tornaram-se gratuitos os transportes da Rêde Ferroviária Federal, transformando os dirigentes a propriedade da União em coisa sua, na escolha do local proibido tudo isso aliado aos pronunciamentos abertamente subversivos dos oradores, caracterizando a mobilização do estilo autoritário, que deveria marcar de modo claro, a marcha para a ditadura. Assim, 
pôs-se à mostra a ousadia sem limites da insignificante minoria de caudilhos e comunistas que, unidos em seu propósito liberticida, querem dominar a imensa maioria democrática, usando dos poderes e recursos que essa mesma maioria lhes outorgou, dessa forma traindo a sua confiança.

Se no excerto anterior, o deputado udenista não mencionava diretamente os "propósitos ditatoriais" de João Goulart, deixando os mesmos num plano subliminar, neste momento, não obstante, os mesmos aparecem como sendo objetivos claramente identificáveis. O Comício da Central do Brasil, nesse sentido, é visto como um estágio de agitação popular em direção da ditadura. Dessa forma, o ato em questão foi, “nos mínimos detalhes”, revelador dessa intenção. Além disso, segundo o parlamentar, a realização do Comício estava eivada de irregularidades e ilegalidades que poderiam, inclusive, suscitar, crime de responsabilidade pelo uso da máquina pública para fins político-eleitorais ou ideológicos, denúncia já abordada em outro pronunciamento direitista neste trabalho: "ousadia [...] nos recursos escandalosamente mobilizados, inclusive os ônibus gigantes das emprêsas de economia mista, desde a Fábrica Nacional de Motores à Cia. Siderúrgica Nacional, à Petrobrás e até mesmo os da Universidade Rural”.

Afirma o deputado que Goulart desafiou o Congresso Nacional, pois esse se configurava naquele contexto como sendo "a pedra no caminho para a ditadura que é preciso remover a qualquer custo". Neste ponto, Levy vale-se de um argumento muito explorado pelas forças direitistas: o presidente, para se manter no poder e conseguir seu plano de reformas de base em direção do "comunismo" estaria de acordo com as ações golpistas propostas pelos setores mais radicais de esquerda. Este argumento soa um tanto exagerado, visto que Goulart demonstrava compromisso com a constitucionalidade das reformas. Entretanto, o possível golpe das esquerdas era francamente explorado pelas forças direitistas e a identificação de Goulart com esse discurso era facilmente construída. Basta levar-se em conta que no "Comício das Reformas", os oradores que antecederam a fala do presidente, como Brizola, falaram abertamente no entrave que o Congresso Nacional representava para o intento reformista da esquerda. Assim, envolver João Goulart num mesmo "bolo esquerdista radical" era tarefa fácil para a oposição. A resposta para esse "golpe esquerdista" "desejado" por Goulart está na "Marcha da família com deus pela liberdade", como aparece na sequência do pronunciamento:

A demonstração do povo de São Paulo gigantesca e sem precedentes na história de meu Estado e mesmo na do País pelas suas proporções, é clara e inequívoca. As setecentas mil ou talvez mesmo um milhão de pessoas que foram para as sacadas, para as ruas e para a praça pública repudiar o totalitarismo e afirmar a sua determinação de viver em liberdade sob a inspiração de Deus, não pode deixar de ser ouvida e não deixará de sê-lo por todos quantos têm parcela de responsabilidade na defesa das instituições.

As vaias ensurdecedoras endereçadas ao Presidente e ao seu cunhado, pela multidão na praça da Sé, em São Paulo, constituem um pronunciamento inequívoco e vale por uma mensagem ao Presidente da República: respeita a 
Constituição ou vá-se embora. A Nação prefere, claramente, uma Constituição sem Presidente do que um Presidente sem Constituição.

É peremptória a classificação das ações pretendidas pelo presidente Goulart na lógica do deputado udenista: tais devem ser vistas como atitudes totalitárias. O povo que saiu às ruas de São Paulo na "Marcha da Família" foi repudiar o "totalitarismo" e "afirmar a sua determinação de viver em liberdade sob a inspiração de Deus". Note-se que o deputado está afirmando que Goulart, além de querer subtrair do povo a democracia e trocá-la pelo totalitarismo soviético, castrista ou mesmo maoísta, ele quer ainda retirar a liberdade das pessoas e, mais, quer retirar do povo a "inspiração de Deus". Daí as senhoras terem empunhado os rosários na Marcha, buscando a proteção divina e, além disso, demonstrando ao presidente e aos "comunistas ateus" a força que Deus tem na vida dos brasileiros. No parágrafo final, uma ameaça a Goulart: ou respeita a Constituição ou vá embora. Nesse particular, duas alternativas parecem relevantes. A primeira delas: em não respeitando a Constituição, o presidente deverá sofrer um processo de impedimento. A segunda alternativa: em não se respeitando a Constituição, o presidente sofrerá um golpe. Já se conhece a história do resultado desta ameaça e suas consequências para o Brasil.

\section{As reações dos parlamentares à posição tomada por Goulart com relação ao protesto dos marinheiros no Rio de Janeiro}

Nesta seção, serão analisados os pronunciamentos dos deputados federais em relação à posição política tomada por João Goulart por ocasião do protesto dos marinheiros, ocorrido em 25 de março de 1964 e que teve lugar no Sindicato dos Metalúrgicos do Rio de Janeiro. ${ }^{23}$ Passando-se diretamente à reação dos deputados federais, a primeira manifestação sobre o tema foi a de Benedito Vaz (PSD/GO): ${ }^{24}$

Desta vez Senhor Presidente o objetivo visado foi a nossa gloriosa Marinha de Guerra. E, nesta tarde, Senhor Presidente, aqui em Brasília, que não sei se será uma das últimas tardes em que aqui nos reunimos, quero dirigir a minha homenagem à Marinha de Tamandaré e de Barroso, àquela brava fôrça que no decorrer da nossa história foi um dos baluartes da independência do Brasil, àquela Marinha de Riachuelo que no auge da luta proclamou: o Brasil espera que cada um cumpra o seu dever.

O deputado inicia o trecho afirmando que a Marinha do Brasil havia sido o mais recente alvo de ataque do presidente da República, evidentemente referindo-se ao conturbado contexto político desde o Comício da Central do Brasil. Afirma estar temerário sobre a instabilidade política do país, quando diz que não sabe se aquele não será um dos seus últimos pronunciamentos, tendo em vista a iminência de um golpe, capitaneado por João Goulart, que teria como objetivo o fechamento do Congresso Nacional. No final do excerto, o parlamentar goiano proclama a exortação da Marinha de Guerra do Brasil no sentido de que aquela força defende o Brasil e sabe cumprir o seu dever. 
Neste excerto, é particularmente interessante a preocupação com a iminência de um golpe nas instituições democráticas do país. Mesmo sem mencionar de que lado será desferido o mesmo, pelo contexto, pode-se inferir que o medo seria mesmo de o golpe ser provocado pelo próprio governo. Sabe-se hoje que o mesmo foi, na verdade, provocado pela oposição. Contudo, é importante registrar o clima de insegurança que tanto a direita como a esquerda alimentavam no momento. Fica muito evidente, não somente pela manifestação em apreço, mas pelo contexto das manifestações dos parlamentares e lideranças políticas de direita, que havia sim uma possibilidade, pelo menos uma hipótese, ainda que, se sabe hoje, muito remota, de um golpe de esquerda no Brasil. Isso porque os sujeitos políticos envolvidos no centro da crise não tinham como antever de onde viria o golpe civil-militar, a menos aqueles diretamente envolvidos na trama. $\mathrm{Na}$ sequência do pronunciamento, o parlamentar faz uma consideração negativa sobre as reformas de base pretendidas por Goulart:

No quinquênio passado o Brasil progredia demonstrava que estava progredindo com um índice que era dos mais elevados do mundo. Não tinha havido reformas de base. Nada disso que hoje é preconizado tinha havido. Entretanto o Brasil se desenvolvia, o Brasil progredia. Neste quinquênio, entretanto, o desenvolvimento parou, está todo estagnado.

O deputado apresenta abertamente sua posição contrária às reformas de base, o que representava uma posição política que comumente não era explicitada com tamanha "sinceridade" pela maioria dos opositores de Jango. O comum nesse tipo de posicionamento dos deputados de direita era afirmar que as reformas de base faziam parte de um projeto de "comunização" do país e que isso seria realizado após o fechamento do Congresso Nacional. Não havia, por parte da oposição, uma discussão substantiva acerca das reformas, somente acusações contra o governo, o que desqualificava o processo das mesmas, uma vez que, do outro lado, os deputados da situação acusavam os oposicionistas de "reacionários", "contrários aos interesses do povo brasileiro" etc. Assim, o debate sobre as reformas foi, no âmbito do governo Goulart, uma conversa entre surdos. A rigor, poucos eram "contrários" às reformas. Contudo, as mesmas não ocorreram, porque não havia acordo em torno delas diante de um debate radicalizado entre as partes. ${ }^{25}$

Dessa forma, a posição assumida por Bendito Vaz era dificilmente enunciada. Mesmo assim, parece que a razão de o deputado ser contrário às reformas era muito clara: o Brasil não tinha necessidade das mesmas. A justificativa também se transparece: no governo do presidente Juscelino Kubitschek, o Brasil cresceu num dos maiores índices do mundo sem a necessidade de quaisquer reformas, sejam constitucionais, sejam de base. Está implícito na fala do parlamentar pessedista que o problema do Brasil não está na sua estrutura institucional ou legal, mas na forma como João Goulart estava conduzindo sua política de governo. O Brasil progredia com Juscelino e "neste qüinqüênio entretanto, o desenvolvimento parou, está todo estagnado”. Segue seu pronunciamento: 
Entregou os pontos mais importantes da administração pública aos agentes de Moscou, inclusive a Petrobrás. E agora entregou os comandos navais todos nas mãos dos comunistas. Fez mais, Senhor Presidente, atentou contra o artigo da Constituição que estabelece que as Fôrças Armadas são fundadas na hierarquia e na disciplina. A hierarquia e a disciplina militares estão destruídas, porque agora quem manda é a subversão que vem de baixo. A desordem provocada pelos marinheiros e pelos cabos impôs um Ministro da Marinha indicado pelo CGT. Até onde chegamos! A que degradação moral, a ponto de um Ministro da Marinha, um Ministro das fôrças militares ser indicado pelo CGT!

Neste ponto, o deputado do PSD retoma o assunto principal do seu pronunciamento. Retoma o mesmo afirmando, inicialmente, que os "pontos mais importantes da administração pública" estão sendo chefiados por "agentes de Moscou". Cita como o exemplo em destaque a Petrobrás, numa referência implícita ao decreto presidencial de encampação das refinarias particulares, assinado por Goulart no Comício da Central do Brasil. Contudo, segundo o deputado, se já não bastasse a presença dos comunistas nos postos mais altos do governo, após a "Revolta dos marinheiros", Goulart entregou o Ministério da Marinha nas mãos dos próprios comunistas. Essa referência é feita tendo em vista que, com a crise provocada pela referida revolta, o Almirante Sílvio Mota pediu exoneração do seu cargo de ministro e foi substituído pelo Almirante Paulo Mário Rodrigues, indicado pelos próprios marinheiros ${ }^{26}$ e também pelo CGT, conforme o deputado. Acusa o presidente neste excerto ainda de atentar contra a Constituição Federal no que concerne à hierarquia e disciplina nas Forças Armadas, "porque agora quem manda é a subversão que vem de baixo", numa clara referência à anistia concedida por Goulart aos marinheiros revoltosos.

Na sequência, será analisado o pronunciamento do deputado Marco Antônio (PST/GB), ${ }^{27}$ em defesa da manifestação dos marinheiros e do governo de João Goulart. Denuncia ainda o deputado da Guanabara, que está sendo arquitetado um golpe de direita no país:

\section{O SR. MARCO ANTÔNIO:}

(Lê a seguinte comunicação) - Senhor Presidente, nas últimas horas, está a Nação Brasileira intranquilizada pela propaganda golpista, já agora abertamente realizada, e que visa a criar um clima para a repetição do 24 de agôsto. Aí estão os editoriais dos jornais de ontem, notadamente do "Jornal do Brasil" a pregarem cinicamente a derrubada do Senhor Presidente da República. Que ironia da sorte, Senhor Presidente, encontramos nestes acontecimentos atuais. Os que acusavam o primeiro magistrado de articular golpes de Estado são agora obrigados a desafivelar a máscara de legalistas e forçados a uma nítida ação golpista.

Neste primeiro momento da manifestação, o deputado da Guanabara, em defesa do governo de João Goulart, acusa a oposição de estar tramando "a derrubada do Senhor Presidente da República". Note-se, neste ponto, a inconstância do momento político em que os pronunciamentos, tanto de direita, como foi visto antes, como de esquerda, tratam da saúde do regime democrático, ameaçada por discursos francamente antagônicos. Neste ponto, é um parlamentar alinhado a Goulart que denuncia abertamente um golpe. É interessante que o deputado faz menção a uma "reedição" do "24 
de agôsto" de 1961, ou seja, a primeira crise que enfrentou Goulart por ocasião da renúncia de Jânio Quadros. Na sequência da sua manifestação:

E o que levou, Senhor Presidente, os golpistas a caírem no desêspero e na ilegalidade? Tão somente uma justa e vitoriosa luta dos marinheiros e fuzileiros navais, movimento que recebeu caloroso apoio da opinião pública e particularmente dos trabalhadores de nossa terra. Os marinheiros e fuzileiros conquistaram a simpatia e a solidariedade dos milhões de brasileiros para sua causa porque ergueram um patético brado contra um regulamento desumano, arcaico e violador da própria dignidade humana. Reivindicam eles o direito de casar, o direito de reunião em sociedade civil legalmente registrada, sociedade que tem como propósito o desenvolvimento cultural e dar assistência a seus associados. Reclamam também os marinheiros e fuzileiros contra o reacionário dispositivo da Constituição que lhes veda o acesso aos pleitos quando são brasileiros dignos e patriotas.

Nesse excerto, o deputado esquerdista faz referência ao conjunto de propostas dos marinheiros revoltosos. Chama a atenção à menção a tais pontos, pois quando ocorreram as acusações direitistas em relação à manifestação, em nenhum momento foi abordada a justiça ou não das reivindicações em si. O deputado afirma que a "opinião pública" apoiou o ato, o que é muito provável, uma vez que o que era demandado pelos marinheiros não era uma mudança radical nas estruturas políticas do país, mas "o direito de casar, o direito de reunião em sociedade civil legalmente registrada, sociedade que tem como propósito o desenvolvimento cultural e dar assistência a seus associados", ou ainda, o direito de serem eleitos para cargos públicos. Como ser contrário a demandas como essas? Os deputados de oposição ao governo não trataram esses pontos em suas manifestações, uma vez que não existiam evidentemente condições de emergência para um discurso contrário a tais reivindicações. Ou alguém será contra o casamento num país católico como o Brasil? Como ser contrário ao direito de reunião, se esse é um direito que os próprios parlamentares exerciam na sua plenitude? Como serem contrários à eleição de militares e correrem o risco de perderem possíveis votos dos seus eleitores defendendo uma medida tão impopular?

Assim, os ataques oriundos da direita restringiram-se à desobediência, à insurgência dos marinheiros para com as ordens, exaradas pelo então ministro da Marinha, Sílvio Mota, para que os revoltosos cessassem a manifestação. A rebelião dos marinheiros foi uma desculpa oposicionista para mais um duelo com o presidente João Goulart e com os deputados da base governista, como pode ser denotado a partir de trecho da manifestação do deputado Amaral Neto (UDN/GB): ${ }^{28}$

Dentro desta Casa assomam à tribuna Deputados que não têm condição moral para fazê-lo [a defesa dos marinheiros revoltosos], porque lá fora se alinham em campanha para dissolução desta Casa. Naquele comício do dia 13 na Guanabara em que ao lado do Presidente da República se encontrava a figura do Sr. Osvaldo Pacheco, sussurrando ao Presidente aquilo que ele esquecia de dizer e gritando muito bem aquilo que ele dizia e que era do seu agrado - naquele Comício um deputado desta Casa pregava o fechamento do Congresso em palavras claras e pedia ao povo que dissesse do seu acôrdo levantando os braços para o alto tal 
como Mussolini, tal como Hitler, tal como Kruchev, tal como Franco, tal como Salazar, tal como Strossener, tal como todos os ditadores do mundo.

O contexto da manifestação, cujo trecho acima foi extraído, era justamente o da Rebelião dos Marinheiros. Contudo, o presente contexto, como foi acima afirmado, estava servindo de pretexto para um novo enfrentamento com o governo federal em relação à participação de João Goulart no Comício da Central do Brasil. Afirma o parlamentar udenista que os deputados que participaram da referida manifestação não têm a "condição moral" para defender os marinheiros revoltosos, porque são justamente aqueles parlamentares que desejam fechar o Parlamento brasileiro. A questão é a seguinte: qual é a relação existente entre um assunto e outro que não somente mais uma oportunidade para atacar o governo? Claramente o deputado faz menção a Leonel Brizola, grande alvo dos seus colegas parlamentares de direita, dizendo que o mesmo estava pregando o fechamento do Congresso Nacional e fazendo poses que rememoravam líderes totalitários e autoritários como Mussolini, Hitler, Kruschev, Franco, Salazar e Strossener.

A questão que parecia estar presente era a de que, efetivamente, não existia mais possibilidade de um debate político em direção a um acordo para manter minimamente a governabilidade no período. Tanto os parlamentares de direita como os de esquerda tinham a clareza de que estavam falando somente para seus próprios pares partidários ou ideológicos.

\section{Os discursos radicalizados em março de 1964 e as posições de direita e de esquerda na} Câmara Federal

Até aqui, foram tratadas as reações discursivas por parte dos deputados federais diante de três acontecimentos marcantes ocorridos em março de 1964 que serviram para radicalizar ainda mais o cenário político do período: o "Comício da Central do Brasil", a "Marcha da Família com Deus pela Liberdade" e o "Protesto dos Marinheiros". Como se viu, tais eventos repercutiram diretamente no ambiente parlamentar no período. Formaram-se, portanto, no contexto político brasileiro daquele fatídico março de 1964 claramente dois discursos antagônicos: um de "direita", outro de "esquerda", um a favor das "reformas de base", outro contrário, um pró-Goulart, outro contrário a Goulart. Neste artigo, tais recorrências discursivas para além da Câmara dos Deputados não foram tratadas. Contudo, as mesmas não podem ser perdidas de vista, uma vez que formam o "pano de fundo" das manifestações acima analisadas. Vejamos, portanto, os dois discursos antagônicos colocados agora em perspectiva comparada.

Assim, o primeiro discurso a ser enfocado será aquele que genericamente tem sido aqui chamado de o discurso da "direita". O termo "direita", como já afirmado, está sendo empregado para designar os opositores do governo Goulart e seu emprego deve-se simplesmente pelo fato de que os defensores do governo assim qualificavam a oposição. O discurso de "direita" possuía 
basicamente três pontos nodais (LACLAU; MOUFFE, 1985), ou seja, três sentidos privilegiados ou centrais. Assim, a "direita” era 1) "anti-Goulart"; 2) "anticomunista" e; 3) alimentava profundas suspeitas com relação ao plano de reformas de base de Jango. Vejamos cada um desses sentidos.

Em relação ao primeiro, não necessariamente todos os deputados direitistas possuíam o mesmo grau de resistência ao governo de João Goulart. A questão apresentava-se de forma mais nebulosa: Goulart não era visto por todos os parlamentares de "direita" como um alvo a ser abatido. $\mathrm{O}$ que era comum a todos eles era o fato de o presidente ser, no mínimo, um adversário e, no máximo, um inimigo, estabelecendo-se aí uma dupla possibilidade dos parlamentares de direita encarar o presidente: seja como adversário, que então se estabelece uma relação agônica, seja como inimigo, momento capaz de estabelecer uma relação antagônica. ${ }^{29}$ Havia, portanto, parlamentares que não tinham a intenção de derrubar Goulart; estes tão-somente discordavam ideologicamente de seu governo e exerciam normalmente a oposição. Assim, como havia outros que tinham intenções mais radicais para contra o presidente.

Já em relação ao "anticomunismo", parece que existia maior homogeneidade no discurso da direita. Os parlamentares reprovavam profundamente a ideia do comunismo. Os políticos de direita criticavam abertamente os apoios que os setores de esquerda, dentre os quais os comunistas, fartamente ofereciam a Goulart. O comunismo era um "horror" comum à direita brasileira. Existia um medo corrente, várias vezes levantado pelos parlamentares, de que o Brasil corria o risco de se transformar numa espécie de Cuba de Fidel Castro.

No que diz respeito às suspeitas que guardavam os deputados de direita em relação às reformas de base apresentadas por Goulart, também não se pode afirmar categoricamente que todos os parlamentares de oposição eram contrários às mesmas. Inicialmente é importante, neste ponto, afirmar que a questão das reformas exerceu papel central no governo de Jango. Vários projetos de reforma agrária oriundos, tanto de partidos de oposição como dos de situação, foram apresentados e não obtiveram aprovação no Congresso Nacional, uma vez que se tratava de uma matéria constitucional e que exigia dois terços de votos para sua aprovação, maioria que nem o governo nem a oposição detinham naquele contexto político. ${ }^{30}$ Tal situação era percebida pelos deputados federais, os quais viam que emendas constitucionais não tinham condições de ser aprovadas num momento antagônico como aquele. ${ }^{31}$ Dessa forma, não se pode categoricamente afirmar que a oposição monoliticamente era contrária a todas as reformas propostas. O medo constante entre os membros da oposição nos momentos finais do governo Jango era o da associação discursiva que se fazia entre "João Goulart", "reformas" e "comunismo", ou seja, se o projeto de reformas do presidente estava recebendo apoio de setores radicais da esquerda, era provável - pelo menos se mostrava um cálculo possível de ser realizado pelos direitistas - que o mesmo tivesse contornos mais radicalizados também. 
Caracterizados os elementos norteadores do discurso da direita, passa-se, neste momento, a tratar do seu corte antagônico, ou seja, a posição política de "esquerda" no final do período Goulart. A utilização do "termo" esquerda para a caracterização deste discurso é dada, tendo em vista que seus próprios sujeitos assim se autodenominavam, por exclusão aos seus inimigos ou adversários de "direita". Feita esta observação, a cadeia de equivalências de "esquerda" no final do período Goulart, composta por uma heterogeneidade de demandas e de identidades, estava articulada a partir dos seguintes pontos nodais, antagônicos aos da cadeia de "direita”, conforme segue: 1) "prógoverno Goulart" e; 2) "reformista ou revolucionária".

O primeiro ponto discursivo privilegiado que constituía o discurso de esquerda, infinitamente mais heterogêneo do que o da direita, era a defesa do governo João Goulart e, por isso, ampliaremos sua abrangência para além dos parlamentares a fim de uma maior compreensão do ponto. Nesse sentido, nos momentos finais do seu período, o presidente conseguiu angariar o apoio de amplos setores das esquerdas, inclusive de algumas de suas vertentes mais revolucionárias. O que foi mais crucial para tal apoio se deveu ao fato de o presidente ter apresentado um conjunto de propostas políticas reformistas que coadunavam com demandas históricas de vários setores de esquerda. Os sargentos e outros militares de baixas patentes, por exemplo, apoiavam o governo Jango, pois, abertamente, o presidente defendeu a universalização do voto no Brasil, o que incluía os analfabetos e todos os militares, independentemente da patente. A CONTAG contava com o presidente da República para a promoção da reforma agrária, uma vez que o Decreto $n^{\circ} 53.700 / 64$ - que declarava de utilidade pública para fins de desapropriação áreas que ladeavam eixos rodoviários federais, ferrovias e terras beneficiadas pela União - assinado no Comício da Central do Brasil, dava indícios claros de tais intenções pelo presidente. O CGT apoiava formalmente o presidente da República, visto que, mesmo tendo sido declarada uma entidade ilegal, Goulart continuava mantendo relações com a mesma e contando com o apoio desta para seu plano de reformas. Os comunistas viam no governo Goulart uma possibilidade de legalização do PCB. Já os parlamentares de esquerda viam em Goulart a possibilidade real de implementação de reformas de base e entendiam que aquele momento era importante para a consecução das mesmas, desde que com apoio popular, o que a esquerda possuía, pelo menos em parte.

O segundo ponto nodal no discurso da esquerda consistia na tensão existente entre "revolução" e "reformas". O mesmo também merece ser analisado ampliando sua abrangência para fora do Congresso. Desta feita, para muitos movimentos de esquerda, o governo Goulart não representava um fim para os seus desígnios, mas um aliado estratégico, pois que, com o apoio do presidente, tais movimentos poderiam avançar em direção de projetos mais ambiciosos. Esses grupos revolucionários não tinham qualquer apreço à democracia, se considerada simplesmente como um método de escolha de lideranças políticas pelo voto direto dos cidadãos. Democracia 
nestes termos meramente formais, para eles, era "democracia burguesa" e, neste âmbito de guerra fria no contexto internacional, plenamente presente na história do Brasil daquele momento, esta deveria ser extirpada, assim como a burguesia de modo geral. O projeto desses setores de esquerda era, portanto, verdadeiramente revolucionário, comunista, como era acusado pelas forças direitistas. O próprio presidente, numa etapa mais avançada desse projeto revolucionário poderia não ser mais necessário e, inclusive, se constituiria num estorvo para o mesmo.

Por este mesmo discurso político de esquerda, além de grupos declaradamente revolucionários, figuravam também grupos democráticos e reformistas. Neste setor, sobejamente formado por parlamentares de esquerda, as reformas de base representavam propostas identificáveis com um projeto político de esquerda e, portanto, isso gerava também a articulação desses parlamentares. É evidente que serem favoráveis às reformas não significava serem revolucionários ou golpistas. Na realidade, o cenário político estava absolutamente radicalizado e posições políticas reformistas poderiam ser facilmente identificadas com posições revolucionárias ou mesmo golpistas. E em que posição está João Goulart nesta cadeia de equivalências?

Inicialmente, João Goulart possuía um lugar de destaque no discurso de esquerda, uma vez que era o pólo articulador do mesmo. Evidentemente que o presidente estava muito mais alinhado aos grupos reformistas do que aos revolucionários. Contudo, no contexto político, a posição de Jango foi constantemente muito incômoda, desde o início de seu governo. O presidente sempre sofreu forte oposição da UDN e mais para o final do seu período, o importante apoio que recebia do PSD também foi perdido. Com isso, Goulart encontrava-se extremamente enfraquecido do ponto de vista institucional e seu governo, portanto, tinha poucos recursos disponíveis para a implementação de seu projeto de reformas políticas.

Naquele março de 1964, o presidente resolveu apostar na estratégia de defender abertamente as insatisfações de setores populares e sindicais de esquerda como meio de pressionar o Congresso Nacional a aprovar as reformas. Usava de meios extraparlamentares como recurso para conseguir governar, num contexto político politicamente radicalizado e economicamente recessivo. Goulart foi ao Comício da Central do Brasil com esse intuito, mesmo contabilizando o preço negativo que poderia pagar, estando no palanque ao lado de lideranças populares nada preocupadas com a manutenção da ordem democrática e dispostas, inclusive, a propor medidas de caráter revolucionário. Goulart certamente não defendia o fechamento do Congresso Nacional uma vez que, em muitos momentos, enfatizou que seus planos reformistas estavam sempre adstritos aos marcos institucionais. Contudo, numa situação de radicalização política crescente era praticamente impossível o presidente não ser classificado pela direita da mesma forma que os grupos radicais que lhe davam sustentação nas ruas. 
Goulart fez uma aposta arriscada para tentar governar num cenário de crescente instabilidade. Evidentemente que o presidente contava com a possibilidade de sua derrubada, pois quando o discurso democrático não é um universal mínimo entre os contendores não há como se pensar, muito menos procurar executar reformas de base, medidas tão ousadas para conservadores tão conservadores como os do Brasil naquela quadra.

O barco estava à deriva, numa tempestade em meio ao turbulento oceano. Mares mais calmos haveriam de aparecer no horizonte e reconduzir a nau novamente para a calmaria, mesmo que momentânea, de uma nova hegemonia.

\section{Referências Bibliográficas}

BONAVIDES, P.; AMARAL, R. Textos políticos da história do Brasil. Vols. VII e IX. Brasília: Senado Federal, 2002. [CD-ROM].

BRASIL. Diários do Congresso Nacional (Câmara dos Deputados - Seção I). Edições de 17 a 31 de março de 1964. Disponível em: http://imagem.camara.gov.br/diarios.asp

DICIONÁRIO HISTÓRICO-BIOGRÁFICO BRASILEIRO PÓS-30. Rio de Janeiro: CPDOC/FGV, 2001.

FIGUEIREDO, A. C. Democracia ou reformas? Alternativas democráticas à crise política (19611964). São Paulo: Paz e Terra, 1993, 210 p.

LACLAU, E. New Reflections on the revolutions of our time. London: Verso, 1990, 284 p.

; MOUFFE, C. Hegemony and socialist strategy: towards a radical democratic politics. London: Verso, 1985, 208 p.

MENDONÇA, D. O discurso da esquerda em março de 1964: as reformas e medo do golpe. Tomo, v. 2, pp. 23-66, 2008.

MOUFFE, C. The democratic paradox. London: Verso, 2000, 192 p.

SANTOS, W. G. O cálculo do conflito: estabilidade e crise na política brasileira. Belo Horizonte/Rio de Janeiro: Editora UFMG/IUPERJ, 2003, 396 p.

SILVA, H. 1964: golpe ou contragolpe? Rio de Janeiro: Editora Civilização Brasileira, 1975, 492p.

\section{NOTAS}

\footnotetext{
${ }^{1}$ Agradeço a leitura atenta e os comentários produzidos pelo parecerista anônimo, os quais foram fundamentais para a redação final deste trabalho.

2 Excerto do pronunciamento do deputado federal Geraldo Freire (UDN/MG), publicado no Diário do Congresso Nacional (Seção I), em 25 de março de 1964, na página 1816.

${ }^{3}$ Todos os pronunciamentos aqui destacados foram transcritos exatamente na forma como os mesmos foram publicados originalmente.
} 


\begin{abstract}
${ }^{4}$ Neste trabalho, entende-se como posição política de "direita" aquela adotada por grupos políticos adversários do governo de João Goulart, ou seja, partidos políticos como a UDN e setores do PSD, grupos como IPES e IBAD e, por consequência, militares e empresários. Desta forma, a "direita" brasileira da época preconiza a retórica da democracia liberal e temia que a mesma fosse solapada a partir de um processo revolucionário de cunho marxista. Além disso, a "direita" tinha apoio da Igreja Católica e acreditava que a posição política de "esquerda" representava uma franca ameaça à "fé cristã" do povo brasileiro.
\end{abstract}

${ }^{5}$ Neste trabalho, entende-se como posição política de "esquerda" aquela adotada pelos movimentos laborais e sociais pró-Goulart (como CGT e UNE, por exemplo), por determinados grupos políticos do PTB (o grupo de Brizola, por exemplo), por organizações clandestinas (como o PCB). Assim, a "esquerda" do espectro político tinha como principais bandeiras a intervenção do Estado na economia e as "reformas de base", sobretudo a agrária, plataforma política claramente defendida por João Goulart neste período. A esquerda ainda varia entre grupos meramente simpáticos à experiência revolucionária em Cuba e ao "socialismo real" e àqueles que eram absolutamente defensores destes regimes de inspiração marxista.

${ }^{6}$ Para uma análise mais aprofundada do Comício da Central do Brasil, sua organização e sentidos políticos produzidos, ver Mendonça (2008)

${ }^{7}$ O presente pronunciamento encontra-se publicado no Diário do Congresso Nacional (Seção I), de 17 de março de 1964, páginas 1553 a 1558.

${ }^{8}$ É importante fazer referência ao fato de que o PSD compôs juntamente com o PTB a chapa para as eleições presidenciais de 1960, sendo Lott o candidato a presidente e Goulart o candidato a vice. Na oportunidade, como as eleições para os cargos de presidente e de vice-presidente eram desvinculadas, Lott foi derrotado por Jânio Quadros e Jango foi eleito. Após a renúncia de Quadros e a ascensão de Goulart à Presidência, num sistema parlamentarista de governo, em setembro de 1961, o PSD, que era o maior partido político da época, indicou o primeiro primeiro-ministro, Tancredo Neves. No período do parlamentarismo, sobretudo tendo em vista as constantes tentativas de Jango de reaver seus poderes presidenciais a partir da antecipação do plebiscito, plebiscito que ocorreu em janeiro de 1963, as relações entre o governo de Goulart e o PSD se deterioraram paulatinamente. Em março de 1964, importantes setores do PSD, partido tradicionalmente conservador, fazia franca oposição a Goulart, ainda mais porque o presidente, neste período, estava alinhado a setores de esquerda, tradicionais adversários dos pessedistas.

${ }^{9} \mathrm{O}$ presente pronunciamento encontra-se publicado no Diário do Congresso Nacional (Seção I), de 17 de março de 1964, na página 1561.

${ }_{10}$ Osvaldo Pacheco era o primeiro-secretário do Comando Geral dos Trabalhadores e um dos responsáveis pela organização do Comício de 13 de março de 1964.

${ }^{11}$ O presente pronunciamento encontra-se publicado no Diário do Congresso Nacional (Seção I), de 17 de março de 1964, nas páginas 1563 a 1565.

${ }^{12}$ Neste ponto, é pertinente fazer referência ao documento publicado por Humberto de Alencar Castello Branco, então Chefe do Estado-Maior do Exército, como a principal manifestação contrária à realização do Comício da Central do Brasil e que foi considerada extremamente importante pelos militares para a condução do golpe de 31 de março de 1964 (BONAVIDES; AMARAL, 2002: Vol. VII doc. 307.6).

${ }^{13}$ O presente pronunciamento encontra-se publicado no Diário do Congresso Nacional (Seção I), de 18 de março de 1964, nas páginas 1598 a 1600.

${ }^{14}$ Antagonismo aqui deve ser entendido no contexto da teoria do discurso de Ernesto Laclau e de Chantal Mouffe (1985), ou seja, como o momento da instituição de uma linha divisória entre dois discursos inimigos. A constituição de um discurso, por conseguinte, se dá negativamente, ou seja, pela ameaça da existência de seu pólo antagônico. O pólo antagônico é, portanto, a condição de possibilidade da constituição do discurso inimigo, no sentido do que Laclau tem chamado, seguindo aí Derrida, de "exterior constitutivo" (LACLAU, 1990).

${ }^{15} \mathrm{O}$ presente pronunciamento encontra-se publicado no Diário do Congresso Nacional (Seção I), de 17 de março de 1964, na página 1553.

${ }^{16} \mathrm{O}$ presente pronunciamento encontra-se publicado no Diário do Congresso Nacional (Seção I), de 17 de março de 1964, na página 1564.

${ }^{17}$ O presente pronunciamento encontra-se publicado no Diário do Congresso Nacional (Seção I), de 17 de março de 1964, nas páginas 1567 e 1568.

${ }^{18} \mathrm{O}$ presente pronunciamento encontra-se publicado no Diário do Congresso Nacional (Seção I), de 18 de março de 1964, na página 1596.

${ }_{19}$ O Dicionário Histórico-Biográfico Brasileiro registra a "Marcha do Rio" com público ainda maior na seguinte passagem: "a iniciativa da Marcha da Família repetiu-se em outras capitais, mas já após a tomada do poder pelos militares, o que as tornou conhecidas como "marchas da vitória". A marcha do Rio de Janeiro, articulada pela Camde [Campanha da Mulher pela Democracia], levou às ruas cerca de um milhão de pessoas no dia 2 de abril de 1964".

${ }^{20}$ O presente pronunciamento encontra-se publicado no Diário do Congresso Nacional (Seção I), de 24 de março de 1964, nas páginas 1756 a 1757.

${ }^{21}$ O presente pronunciamento encontra-se publicado no Diário do Congresso Nacional (Seção I), de 24 de março de 1964, na página 1758.

${ }^{22} \mathrm{O}$ presente pronunciamento encontra-se publicado no Diário do Congresso Nacional (Seção I), de 25 de março de 1964, nas páginas 1818 a 1820. 
${ }^{23}$ A "Revolta dos marinheiros" pode ser considerada como o segundo grande exemplo de insubordinação militar. O primeiro, conhecido como a "Revolta dos Sargentos", ocorreu em 3 de setembro de 1963 no âmbito do Exército. Conforme Silva, "no dia 3 de setembro de 1963 houve um levante em Brasília quando seiscentas praças da guarnição militar do Distrito Federal insurgiram-se contra a cassação dos mandatos eletivos dos sargentos pelo Supremo Tribunal Federal. O movimento foi prontamente sufocados e os sargentos e os soldados que os acompanharam foram presos [...]" (SILVA, 1975, p.355). Já as reivindicações da "Revolta dos Marinheiros", sob o comando de José Anselmo dos Santos, conhecido como cabo Anselmo, eram as seguintes: o reconhecimento da Associação dos Marinheiros e dos Fuzileiros Navais, a melhoria da alimentação nos navios e quartéis e a reformulação do regulamento disciplinar da Marinha (DHBB, 2001). A revolta terminou no dia seguinte, sendo os marinheiros presos e, logo após, anistiados por João Goulart. "Essa anistia foi criticada por sucessivos manifestos da alta oficialidade, agravando ainda mais a crise na área militar" (DHBB, 2001, p.4992).

${ }^{24} \mathrm{O}$ presente pronunciamento encontra-se publicado no Diário do Congresso Nacional (Seção I), de 31 de março de 1964, na página 1893.

25 Acerca da radicalização dos debates sobre as reformas de base no contexto do Congresso Nacional, são muito ilustrativas e precisas às análises de Figueiredo (1993) e Santos (2003).

${ }^{26}$ A fonte que afirma ter sido o almirante Paulo Mário Rodrigues indicado para ministro da Marinha está contida no Dicionário Histórico-Biográfico Brasileiro (DHBB, 2001, p.5112-5113). Tal afirmação, cotejada com o pronunciamento em análise, faz pleno sentido, pois para os parlamentares de direita, os marinheiros favoráveis às reformas de base de Goulart, eram considerados também "comunistas".

${ }^{27}$ O presente pronunciamento encontra-se publicado no Diário do Congresso Nacional (Seção I), de 31 de março de 1964, na página 1894.

${ }^{28}$ O presente pronunciamento encontra-se publicado no Diário do Congresso Nacional (Seção I), de 31 de março de 1964, na página 1895.

${ }^{29}$ As expressões "antagonismo" e "agonismo" estão sendo aqui empregadas no sentido proposto por Chantal Mouffe (2000). Antagonismo, conceito já explicado anteriormente, pode ser entendido como uma "luta entre inimigos", cujo objetivo é a destruição mútua. Já o termo agonismo apresenta a ideia da luta entre adversários, os quais compartilham uma série de regras previamente estabelecidas e que regem suas batalhas. Um exemplo de agonismo é a disputa no âmbito do parlamento. No caso específico deste artigo, o que se buscou analisar foram os debates agônicos entre os parlamentares em relação aos eventos ocorridos em março de 1964.

${ }^{30}$ Neste ponto, é importante ter presente a análise que Wanderley Guilherme dos Santos faz do período, quando atribui que existia, na verdade uma "paralisia decisória", constatadas a partir de três condições, a saber: "fragmentação política, polarização ideológica, e instabilidade de coalizões" (SANTOS, 2003, p. 265).

${ }^{31} \mathrm{O}$ deputado Amaral Neto (UDN/GB) exemplifica com exatidão a impossibilidade de aprovação de qualquer matéria que necessite maioria absoluta dos votos na Câmara Federal: “os traidores nesta Casa, que aqui têm assento, não podem ter seu mandato cassado, porque aqui não há dois terços para nada. E a Nação precisa saber que não há dois terços nem para emendar a Constituição, como não há para cassar mandatos, como não há para votar impeachment. Estamos colocados diante de fato consumado que nos tira todos os remédios legais para as providências legais que deveríamos tomar" (Diário do Congresso Nacional, Seção I, 31 de março de 1964, p. 1895).

Artigo recebido em 11/2009. Aprovado em 01/2010. 